\title{
Regional modeling of carbonaceous aerosols over Europe-focus on secondary organic aerosols
}

\author{
Bertrand Bessagnet • Laurent Menut • Gabriele Curci • Alma Hodzic • \\ Bruno Guillaume • Catherine Liousse - Sophie Moukhtar • Betty Pun • \\ Christian Seigneur • Michaël Schulz
}

\begin{abstract}
In this study, an improved and complete secondary organic aerosols (SOA) chemistry scheme was implemented in the CHIMERE model. The implementation of isoprene chemistry for SOA significantly improves agreement between long
\end{abstract}

B. Bessagnet ( $\otimes)$

INERIS, Institut National de l'Environnement Industriel et des Risques,

Parc technologique ALATA, 60550 Verneuil en Halatte, France

e-mail: bertrand.bessagnet@ineris.fr

\section{Menut}

Institut P.-S. Laplace, Laboratoire de Météorologie Dynamique,

Ecole Polytechnique, 91128 Palaiseau, France

G. Curci

CETEMPS, Università degli Studi dell'Aquila, via Vetoio, 67010 Coppito - L'Aquila, Italy

\section{A. Hodzic}

NCAR, National Center for Atmospheric Research,

3450 Mitchell Lane, Boulder, 80301, CO, USA

B. Guillaume · C. Liousse

LA/OMP, Laboratoire d'Aérologie / Observatoire Midi-Pyrénées,

14, avenue Edouard Belin, 31400 Toulouse, France

S. Moukhtar

Centre for Atmospheric Chemistry, York University,

4700 Keele Street, Toronto, Canada

B. Pun · C. Seigneur

Atmospheric \& Environmental Research, 2682 Bishop Drive,

Suite 120, San Ramon, CA 94583, USA

M. Schulz

Laboratoire des Sciences du Climat et de l'Environnement,

IPSL/CEA-CNRS-UVSQ, 91190 Gif-sur-Yvette, France 
series of simulated and observed particulate matter concentrations. While simulated organic carbon concentrations are clearly improved at elevated sites by adding the SOA scheme, time correlation are impaired at low level sites in Portugal, Italy and Slovakia. At several sites a clear underestimation by the CHIMERE model is noticed in wintertime possibly due to missing wood burning emissions as shown in previous modeling studies. In Europe, the CHIMERE model gives yearly average SOA concentrations ranging from $0.5 \mu \mathrm{g} \mathrm{m}^{-3}$ in the Northern Europe to $4 \mu \mathrm{g} \mathrm{m}^{-3}$ over forested regions in Spain, France, Germany and Italy. In addition, our work suggests that during the highest fire emission periods, fires can be the dominant source of primary organic carbon over the Mediterranean Basin, but the SOA contribution from fire emissions is low. Isoprene chemistry has a strong impact on SOA formation when using current available kinetic schemes.

Keywords Secondary organic aerosols • Modeling • Isoprene • Monoterpenes • Elemental carbon • Organic carbon

\section{Introduction}

Particulate matter (PM) pollution control is one of the main challenges highlighted by the Thematic Strategy on Air Pollution (CAFE as Clean Air For Europe), adopted by the European Commission in October 2005, under its $6^{\text {th }}$ Environmental Action Program (Decision $N^{o} 1600 / 2002 / E C$ of the European Parliament and of the Council of July 22, 2002 laying down the Sixth Community Environment Action Programme). The CAFE strategy states that particulate matter (and especially fine particles with diameter smaller than and equal to $2.5 \mu \mathrm{m}-\mathrm{PM}_{2.5}$ ) is responsible today for an average reduction of life expectancy of about 8 months in Europe: recent epidemiological studies highlight the role of the smallest part of these particles on health (Schlesinger 2006; Lee et al. 2007; Heinrich and Slama 2007). Fine particles are composed of a large fraction of organic and elemental carbon (OC and EC) that can be directly injected in the atmosphere (Putaud et al. 2004; Van Dingenen et al. 2004). The so-called secondary organic aerosols (SOA) are formed by chemical reactions of volatile organic compounds (VOCs) in the atmosphere including monoterpenes and isoprene emitted by vegetation (Kroll and Seinfeld 2008; Surratt et al. 2006). While in winter domestic wood burning emissions are the main sources of OC with sizable additional contribution from fossil fuel combustion, SOA mainly originating from non fossil sources largely contribute to OC in summer. Based on the CARBOSOL measurements (Pio et al. 2007; Legrand and Puxbaum 2007; Gelencsér et al. 2007), non fossil sources were expected to represent $63-76 \%$ of the total carbon $(\mathrm{TC}=$ $\mathrm{OC}+\mathrm{EC})$. Moreover, $50-80 \%$ of OC is water soluble and suggests that $\mathrm{OC}$ has to be considered in discussing the role of clouds on climate over Europe (Gelencsér et al. 2007; Pio et al. 2007). Humic-like substances (HULIS) are other contributors of water soluble compounds (3-7\%) and are directly emitted by biomass burning and possibly formed by chemical reactions in the atmosphere (Mayol-Bracero et al. 2002; Graber and Rudich 2006; Lukács et al. 2007; Schmidl et al. 2008; Altieri et al. 2008). Most OC is contained in oligomeric or polymeric matter (Legrand and Puxbaum 2007). OC directly emitted by the decomposition of vegetative debris is another 
source of the organic coarse size fraction (Puxbaum et al. 2003), a contribution of $6 \%$ was attributed in remote background sites (Bauer et al. 2002). In the frame of the CARBOSOL campaign, the modeled EC and OC concentration fields of the EMEP model were compared to measurements. OC was generally underpredicted in most of the sites certainly due to missing wood burning contributions. The model underpredicted TC in the southern Europe mainly due to a lack of SOA (Simpson et al. 2007). For EC, the largest uncertainties probably lie in EC emissions from residential wood/fossil combustion possibly associated with both emission factors and spatial and temporal variation (Tsyro et al. 2007). During a specific modeling intercomparison exercise, a potential large underestimation of carbonaceous species concentrations has been recently reported in Eastern Germany due to underestimated sources in Eastern Europe (Stern et al. 2008). Over the United States, the role of isoprene in secondary organic aerosol formation has been extensively studied (Dommen et al. 2006; Kroll et al. 2006; van Donkelaar et al. 2007; Zhang et al. 2007). Previous studies suggest a high sensitivity to the values of the enthalpy of vaporization used in models (Zhang et al. 2007; Henze and Seinfeld 2006). Another survey showed for secondary organic carbon a $30 \%$ maximum contribution to the total secondary carbon at a southeastern US location (Kleindienst et al. 2007).

Objectives of the study The CHIMERE model was previously validated on $\mathrm{PM}_{10}$, sulfate, nitrate and ammonium components (Bessagnet et al. 2004, 2005; Vautard et al. 2005; Hodzic et al. 2005). In this work, a new SOA scheme has been implemented in CHIMERE, a new emission inventory for biogenic VOC emissions MEGAN has also been used. Our work is the first one focussing over Europe by accounting for terpene chemistry including isoprene for SOA formation at high resolution. One of the first work on SOA modeling in Europe was done by Schell et al. (2001) with the SORGAM model. Most of the recent modeling studies did not focus on Europe and/or used low horizontal resolutions with global models (Liao et al. 2007; Tsikaridis and Kanakidou 2007). For instance, in our research field, the most recent relevant modeling study over Europe with the EMEP model did not account for isoprene chemistry for SOA formation (Simpson et al. 2007). Our work complements the knowledge on SOA modeling in Europe and proposes new insights. A first evaluation of the CHIMERE model is proposed for carbonaceous species by using OC and EC observations from the CARBOSOL and EMEP available data for year 2003. This year was characterized by huge fire emissions in the southern Europe. SOA issued from fire emissions are accounted for in this work. Our work investigates the contribution of fire emissions on OC concentrations.

\section{Usual identified gaps in SOA modeling}

SOA modeling remains highly uncertain and too simple, they need to be improved by adding aqueous and heterogeneous pathways, as well as taking into account the multi-step oxidation processes and their dependence on the NOx regime (Pun and Seigneur 2007). One important weakness was identified to be the estimate of biogenic precursor emissions. A first step towards improving our SOA knowledge is improvements of the biogenic emission inventories (Simpson et al. 2007; Arneth 
et al. 2008). Another improvement is the quality of meteorological data feeding the model. For instance, an underestimation of temperatures implies three kind of issues: (i) an underestimation of total SOA formation because of kinetic rates favored by high temperature, (ii) an underestimation of SOA concentrations because of lower biogenic emissions, and (iii) an overestimate of gas to particle transfert of semivolatile SOA. Another work (Shrivastava et al. 2006) suggests that particle emission factors could be underestimated because they are calculated at given temperature, relative humidity and dilution ratio in order to avoid artefacts during the sampling process. In so doing, a non negligible fraction, the so-called SVOCs (semi-volatile VOCs), may have not been taken into account in current gas and particle emission inventories when these data are applied for modeling "real" atmospheres. Moreover, recent studies pointed out the possible role of primary SVOCs in SOA formation (Robinson et al. 2007; Donahue et al. 2006; Schauer et al. 2002). These precursors evaporate during the emission dilution process and could be converted into the particulate phase after oxidation. The exact physical and chemical pathways to secondary organic aerosol for most parent hydrocarbons are still uncertain and during the last ten years, the condensation/sorption process has been adopted in models (Pankow 1994; Bowman et al. 1997). Nucleation bursts were observed in rather clean environments such as boreal forest (Kavouras et al. 1998), and in urban areas, assuming co-nucleation effects with sulfuric acid (Fan et al. 2006). If in urban areas absorption certainly dominates, the issue is still open over forested and remote areas (Svendby et al. 2008; Wexler and Johnston 2008; Bonn and Moortgat 2002; Holmes 2007). In clean environment (Arctic), a high amount of dicarboxylic acids such as glutaric, malonic, succinic and glutaric acid was discovered in coarse particles (Kerminen et al. 1999). These acids were observed in coarse urban and suburban aerosols corroborating the possible condensation/sorption of semi-volatile species onto pre-existing coarse particles in summer (Jaffrezo et al. 2005) or the possible role of in-cloud processes (Hsieh et al. 2007; Oliveira et al. 2007). Then, the way of modeling gas to particle conversion will have a strong impact on particle concentrations and compositions. Implementing nucleation processes for SOA in chemistry transport models (not yet available) could shift mass distributions towards smaller particles.

\section{The chemistry transport model CHIMERE}

\subsection{General description}

Given a set of $\mathrm{NO}_{x}, \mathrm{SO}_{x}, \mathrm{NH}_{3}, \mathrm{PM}$, VOCs and $\mathrm{CO}$ emissions, the CHIMERE model calculates the concentrations of 44 gas-phase and aerosol species (Schmidt et al. 2001; Bessagnet et al. 2004). In this study, a version of CHIMERE for a domain covering the western Europe is used: from $14^{\circ} \mathrm{W}$ to $28^{\circ} \mathrm{E}$ in longitude and from $35^{\circ} \mathrm{N}$ to $58.2^{\circ} \mathrm{N}$ in latitude, with a constant horizontal resolution of $0.4^{\circ} \times 0.4^{\circ}$. The vertical grid contains 15 layers from surface to $500 \mathrm{hPa}$. Improvements have successively been brought in previous studies (Vautard et al. 2003, 2005). The model documentation can be found on the web server http://euler.lmd.polytechnique.fr/chimere. For both ozone and $\mathrm{PM}_{10}$, the model has undergone extensive intercomparisons on aerosol 
concentrations at European and city scales (Vautard et al. 2007; Van Loon et al. 2007; Schaap et al. 2009).

Anthropogenic gas emissions are taken from the EMEP inventory (Vestreng 2003). Three particulate model species are considered, PPM (primary particle material) that contains only mineral dust anthropogenic in origin, OC and EC. Coarse particles from the EMEP inventory is the only PPM source. Primary OC and EC assumed to be in the fine mode are issued from a specific inventory discussed in the next section. Calculation of model species emissions that are used by the CHIMERE Chemistry Transport Model, is made in several steps. The spatial emission distribution from the original grid to the CHIMERE grid is performed using an intermediate fine grid with a $0.083^{\circ}$ resolution issued from the GLCF dataset (Hansen et al. 2000). Soil types are known on the fine grid allowing for a better apportionment of the emissions according to urban, rural, maritime and continental areas. Standard time variation profiles are applied to get hourly emissions from annual data, as required by the model. The other modeled species are sulfate, nitrate, ammonium, secondary organic aerosol, sea-salt (considered as inert here) and dust. The particle size distribution ranges from about $40 \mathrm{~nm}$ to $10 \mu \mathrm{m}$ and is distributed into 8 bins. The 8 bins used are defined between the following intervals: $0.039,0.078$, $0.156,0.312,0.625,1.25,2.5,5,10 \mu \mathrm{m}$. The gas/particle partitioning of the ensemble Sulfate/Nitrate/Ammonium is treated by the code ISORROPIA (Nenes et al. 1998) implemented in CHIMERE. For the main gas and aerosols, boundary conditions are issued from a 5-year climatology (2001-2005) of the global model LMDzT-INCA. For aerosol boundary conditions, only elemental and organic carbon, desert dust and sulfate are taken into account. The LMDzT-INCA model contains a multi-modal aerosol distribution (Textor et al. 2006; Schulz et al. 2006), and uses the AeroCom emissions (Dentener et al. 2006). Organic and elemental carbon are described as belonging to a soluble and insoluble accumulation mode, where ageing processes transfer constantly insoluble matter into the soluble aerosol mode.

\subsection{Meteorology}

The CHIMERE model is driven on a hourly base by the meteorological model MM5 for the dynamical parameters (wind, temperature, humidity, pressure). In order to be consistent with the PREVAIR operational forecast system using MM5 and CHIMERE, the current MM5 configuration (Dudhia 1993) was chosen to be the same as the one used and validated during the last 3 years for the daily forecast (Honoré et al. 2008). The MM5 vertical grid contains 32 levels ranging from surface to $10 \mathrm{hPa}$. The horizontal resolution is $54 \mathrm{~km}$ over a domain encompassing the european CHIMERE domain. The meteorological boundary conditions as well as the nudging four-dimensional data assimilation (FDDA) are performed with the sixhourly ECMWF analysis meteorological fields.

Temperature is one of the most important variable for SOA formation. Figure 1 displays a comparison of MM5 simulated 2-m temperatures against observations in summertime. Whereas the time evolution is fairly reproduced, a negative bias is observed in all the cities. The lowest temperatures are mainly affected by this negative bias. The maximum temperatures are the most underestimated in Milan, for Madrid the predicted 2-m temperatures agree well with observations. Such biases are often reported in MM5 simulations (Jiménez et al. 2006; Hogrefe et al. 2001). 

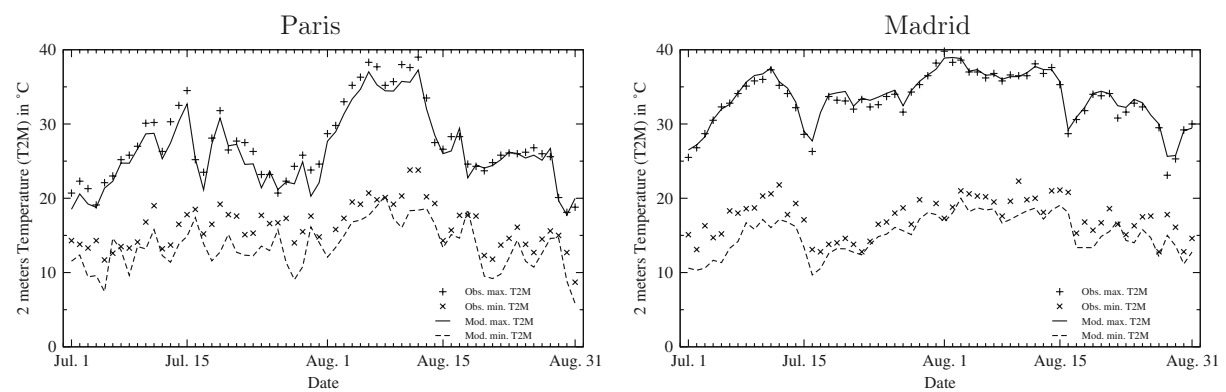

Frankfurt
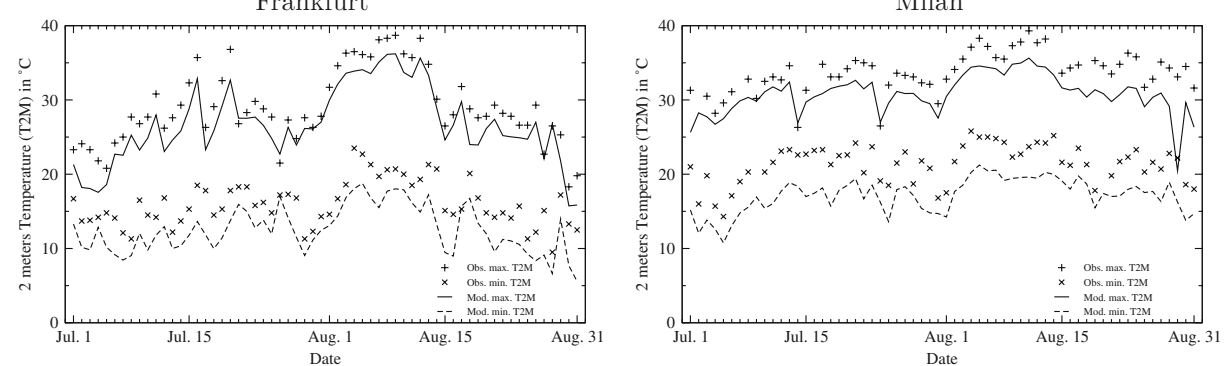

Fig. 1 Evaluation of MM5 predictions for daily minimum and maximum 2-m temperatures in July-August 2003. Stations are: Paris $\left(49.00^{\circ} \mathrm{N}, 2.52^{\circ} \mathrm{E}\right)$, Madrid $\left(40.43^{\circ} \mathrm{N},-3.68^{\circ} \mathrm{E}\right)$, Frankfurt $\left(50.12^{\circ} \mathrm{N}, 8.68^{\circ} \mathrm{E}\right)$, Milan $\left(45.46^{\circ} \mathrm{N}, 9.16^{\circ} \mathrm{E}\right)$

Temperatures were particularly high during the 2003 heat wave in Western Europe, between 35 and $40^{\circ} \mathrm{C}$ for the maximum temperature within the first decade of August 2003. The specific warming process was enhanced by very low soil moisture (Black et al. 2004). The coarse resolution of the model can explain a part of the bias, when comparing to surface measurements in sites such as Frankfurt and Milan. These urbanized areas are surrounded by mountains or near great lakes, the model will give an averaged view of the meteorology, certainly not representative of the city located inside the corresponding model cell.

\subsection{Anthropogenic OC and EC emissions over Europe}

A particular effort has been put on primary OC (OCp) and EC emission inventories emitted by fossil fuel and biofuel combustion (traffic, industry, residential sources), which are key elements in EC and OC modeling. These emissions that are traditionally obtained by bottom-up approaches, are still hampered by severe uncertainties resulting from large differences in the choice of emission factors. Two major different approaches for deriving global fossil fuel and biofuel EC and OCp emission inventories are currently available (Junker and Liousse 2008; Bond et al. 2004), with the main difference between Junker and Liousse (2008) and Bond et al. (2004) being in technology differentiations. In the following, JUNKER2008 is the inventory described in Junker and Liousse (2008) and BOND2004 the one described in Bond et al. (2004). At the European scale, detailed inventories are given for EC and OCp emissions in (Schaap et al. 2004). Thus, in BOND2004 each fossil fuel was considered as a detailed list of combustion technologies and emission 
controls with associated emission factors (EF). In JUNKER2008, for each fuel, two parameters characterize the emissions: (i) the activity sector (domestic, industrial, traffic), and (ii) the national level of development (with three levels: developed, semi-developed and developing countries). In each of these methods, the part of uncontrolled emissions is differently handled which is the origin of their largest differences. Higher estimated emissions may be found for the major fuels (coal, diesel, peat, lignite, coke) in JUNKER2008 than in BOND2004, with more controlled emissions in BOND2004 than in JUNKER2008. Harmonization between these two inventory types is in progress at a global scale. A technology-splitting approach has been adopted with the same considerations of emission controls as in Schaap et al. (2004) and in BOND2004, while keeping EF values estimated from JUNKER2008. With such a configuration, both newer combustor types and "large emitters" that still exist in Europe, are taken into account. The IIASA (International Institute for Applied Systems Analysis, http:/www.iiasa.ac.at) fuel dataset (Klimont et al. 2002) are used, covering 35 European countries excluding Russia and Ukraine and including informations on controlled and uncontrolled fractions of fuel use, which depend on emission control set up. Waste burning is not included. Emission factors (EF) for EC and OCp are obtained from Junker and Liousse (2008), using a proxy when EF values are not well known. Variation of ratio EC versus total particulate matter is the usual proxy used to derive unknown EF values. This proxy is based on the relationships between $E C / O C p$ and $\mathrm{CO} / \mathrm{CO}_{2}$ ratios. It is noteworthy that an improved spatial distribution of EC and OCp emissions than in previous inventories is used with traffic and domestic emissions scaled on rural and urban population densities, but industrial emissions spatialized according to their real geographical positions and magnitudes. A comparison between this inventory with Schaap et al. (2004) is proposed in Guillaume et al. (2007). In both inventories, EC from brown coal and hard coal fuels dominates while slowly replaced by diesel, the relative importance of wood contribution is comparable. Fuel consumption is generally in agreement. Main differences occur in the relative importance of controlled and uncontrolled fractions of fuel use and in brown and hard coal emission factors selected for industrial and domestic sectors. Emission factors in Schaap et al. (2004), based on BOND2004, values are smaller than those in Guillaume et al. (2007). Industrial emissions (especially power plant emissions) are more controlled in Schaap et al. (2004) than in the inventory used in this work. These differences are particularly important for Poland emissions, much higher in this inventory than in Schaap et al. (2004). Same differences exist for domestic emissions while traffic emissions are comparable. Finally, this European EC inventory is about 1.5 times higher than in Schaap et al. (2004), while in agreement with the European zoom of JUNKER2008 inventory. Both inventories have been tested in ORISAM-TM4 global transport model (Guillaume et al. 2007, 2008). Following these results, EC and OCp European emission inventories for year 2000 and built with a $25 \mathrm{~km} \times 25 \mathrm{~km}$ resolution, have been selected in our study. These emissions are extrapolated to the CHIMERE resolution.

\subsection{Fire emissions}

In the past decade, wildfires have devastated vast areas of forest and agricultural lands across Europe. In 2003 alone, more than 650,000 ha of forest area and about 
45,000 ha of agricultural land have been destroyed in Europe, which released into the atmosphere large amount of smoke particles and trace gases (such as $\mathrm{CO}, \mathrm{CO}_{2}$, VOCs, $\mathrm{NO}, \mathrm{NO}_{2}$, etc...). The 2003 wildfire emissions contributed significantly to the enhancement of carbonaceous aerosol concentrations and perturbations of the surface radiative balance. In order to accurately assess the effects of wildfires on the atmospheric chemistry and radiative budget, the amount of emitted species needs to be quantified. In this study, and in the same way than in Hodzic et al. (2007), daily wildfire emissions of particulate matter and trace gases together with their geographic locations were estimated based on satellite information including (i) the location and date of the fire event, (ii) the area burned, (iii) the fuel loading factors (mass of biomass per area), (iv) the fraction of biomass fuel burned, and (v) the emission factors. These parameters have been determined by combining data available from several satellite products according to the methodology described in Wiedinmyer et al. (2006). The VOC speciation prescribed in EPA (1993) was used. A detailed description of the emission dataset is given in Hodzic et al. (2007).

\subsection{SOA modeling in CHIMERE}

A specific SOA module has been used for this study, the complete chemical scheme implemented in CHIMERE includes biogenic and anthropogenic precursors (Table 1). Biogenic precursors include API ( $\alpha$-pinene and sabinene), BPI $(\beta$ pinene and $\delta^{3}$-carene), LIM (limonene), TPO (myrcene and ocimene) and ISO

Table 1 Gas phase chemical scheme for SOA formation in CHIMERE

\begin{tabular}{ll}
\hline Reactions & Kinetic rates $\left(\right.$ molecules $\left.^{-3} s^{-1}\right)$ \\
\hline $\mathrm{TOL}+\mathrm{OH} \rightarrow 0.004 \times \mathrm{AnA} 0 \mathrm{D}+0.001 \times \mathrm{AnA} 1 \mathrm{D}$ & $1.81 \times 10^{-12} \mathrm{exp}(355 / \mathrm{T})$ \\
$\quad+0.084 \times \mathrm{AnBmP}+0.013 \times \mathrm{AnBlP}$ & \\
$\mathrm{TMB}+\mathrm{OH} \rightarrow 0.002 \times \mathrm{AnA} 0 \mathrm{D}+0.002 \times \mathrm{AnA} 1 \mathrm{D}$ & $9.80 \times 10^{-9} / \mathrm{T}$ \\
$\quad+0.001 \times \mathrm{AnA} 2 \mathrm{D}+0.088 \times \mathrm{AnBmP}+0.006 \times \mathrm{AnBlP}$ & \\
$\mathrm{NC} 4 \mathrm{H} 10+\mathrm{OH} \rightarrow 0.07 \times \mathrm{AnBmP}$ & $1.36 \times 10^{-12} \mathrm{exp}(190 / \mathrm{T})^{-2}$ \\
$\mathrm{API}+\mathrm{OH} \rightarrow 0.30 \times \mathrm{BiA} 0 \mathrm{D}+0.17 \times \mathrm{BiA} 1 \mathrm{D}+0.10 \times \mathrm{BiA} 2 \mathrm{D}$ & $1.21 \times 10^{-11} \mathrm{exp}(444 / \mathrm{T})$ \\
$\mathrm{API}+\mathrm{O} 3 \rightarrow 0.18 \times \mathrm{BiA} 0 \mathrm{D}+0.16 \times \mathrm{BiA} 1 \mathrm{D}+0.05 \times \mathrm{BiA} 2 \mathrm{D}$ & $1.01 \times 10^{-15} \mathrm{exp}(-732 / \mathrm{T})$ \\
$\mathrm{API}+\mathrm{NO} 3 \rightarrow 0.80 \times \mathrm{BiBmP}$ & $1.19 \times 10^{-12} \mathrm{exp}(490 / \mathrm{T})$ \\
$\mathrm{BPI}+\mathrm{OH} \rightarrow 0.07 \times \mathrm{BiA} 0 \mathrm{D}+0.08 \times \mathrm{BiA} 1 \mathrm{D}+0.06 \times \mathrm{BiA} 2 \mathrm{D}$ & $2.38 \times 10^{-11} \mathrm{exp}(357 / \mathrm{T})$ \\
$\mathrm{BPI}+\mathrm{O} 3 \rightarrow 0.09 \times \mathrm{BiA} 0 \mathrm{D}+0.13 \times \mathrm{BiA} 1 \mathrm{D}+0.04 \times \mathrm{BiA} 2 \mathrm{D}$ & $1.50 \times 10^{-17}$ \\
$\mathrm{BPI}+\mathrm{NO} 3 \rightarrow 0.80 \times \mathrm{BiBmP}$ & $2.51 \times 10^{-12}$ \\
$\mathrm{LIM}+\mathrm{OH} \rightarrow 0.20 \times \mathrm{BiA} 0 \mathrm{D}+0.25 \times \mathrm{BiA} 1 \mathrm{D}+0.005 \times \mathrm{BiA} 2 \mathrm{D}$ & $1.71 \times 10^{-10}$ \\
$\mathrm{LIM}+\mathrm{O} 3 \rightarrow 0.09 \times \mathrm{BiA} 0 \mathrm{D}+0.10 \times \mathrm{BiA} 1 \mathrm{D}$ & $2 \times 10^{-16}$ \\
$\mathrm{TPO}+\mathrm{OH} \rightarrow 0.70 \times \mathrm{BiA} 0 \mathrm{D}+0.075 \times \mathrm{BiA} 1 \mathrm{D}$ & $5.10 \times-8 / \mathrm{T}$ \\
$\mathrm{TPO}+\mathrm{O} 3 \rightarrow 0.50 \times \mathrm{BiA} 0 \mathrm{D}+0.055 \times \mathrm{BiA} 1 \mathrm{D}$ & $7.50 \times 10^{-14} / \mathrm{T}$ \\
$\mathrm{TPO}+\mathrm{NO} 3 \rightarrow 0.70 \times \mathrm{BiA} 0 \mathrm{D}+0.075 \times \mathrm{BiA} 1 \mathrm{D}$ & $4.30 \times 10^{-9} / \mathrm{T}$ \\
$\mathrm{ISO}+\mathrm{OH} \rightarrow 0.232 \times \mathrm{ISOPA} 1+0.0288 \times \mathrm{ISOPA} 2$ & $2.55 \times 10^{-11} \mathrm{exp}(410 / \mathrm{T})$
\end{tabular}

The surrogate SOA compounds consist of six hydrophilic species that include an anthropogenic non-dissociative species (AnA0D), an anthropogenic once-dissociative species (AnA1D), an anthropogenic twice-dissociative species (AnA2D), a biogenic non-dissociative species (BiA0D), a biogenic once-dissociative species (BiA1D) and a biogenic twice-dissociative species (BiA2D), three hydrophobic species that include an anthropogenic species with moderate saturation vapor pressure $(\mathrm{AnBmP})$, an anthropogenic species with low saturation vapor pressure (AnBlP) and a biogenic species with moderate saturation vapor pressure $(\mathrm{BiBmP})$, and two surrogate compounds for the isoprene oxidation products (ISOPA1, ISOPA2). $\mathrm{T}$ is the temperature in $\mathrm{K}$. 
(isoprene). Anthropogenic precursors include TOL (benzene, toluene and other mono-substituted aromatics), TMB (Trimethylbenzene and other poly-substituted aromatics), and $\mathrm{NC} 4 \mathrm{H} 10$ (higher alkanes). SOA formation is represented according to a single-step oxidation of the relevant precursors and gas-particle partitioning of the condensable oxidation products. The gas-particle partitioning formulation has been described in detail in Pun et al. (2006). The overall approach consists in differentiating between hydrophilic SOA that are most likely to dissolve into aqueous inorganic particles and hydrophobic SOA that are most likely to absorb into organic particles. The dissolution of hydrophilic SOA is governed by Henry's law whereas the absorption of hydrophobic particles is governed by Raoult's law. The large number of condensable organic compounds is represented by a set of surrogate compounds that cover the range of physico-chemical properties relevant for aerosol formation, i.e., water solubility and acid dissociation for hydrophilic compounds and saturation vapor pressure for hydrophobic compounds. These surrogate compounds were selected by grouping identified particulate-phase molecular products with similar properties. The molecular weight of each surrogate compound is determined based on its structure and functional groups. The Henry's law constant or the saturation vapor pressure of the surrogate species is derived from the average properties of the group. Other properties are estimated using the structure of each surrogate compound. Enthalpy of vaporization are given in brackets $\left(\mathrm{kJ} \mathrm{mol}^{-1}\right)$ for each SOA compounds: AnA0D (88), AnA1D(88), AnA2D(88), BiA0D(88), $\operatorname{BiA} 1 D(88), \operatorname{BiA} 2 D(109), \operatorname{AnBmP}(88), \operatorname{AnBlP}(88), \operatorname{BiBmP}(175)$. The full name of compounds are given in Table 1 caption. The absorption process in CHIMERE is implemented as in Bowman et al. (1997). A dynamical approach is adopted to describe the gas/particle conversion since the model time-step is about $5 \mathrm{~min}$ and using the approach described in Bowman et al. (1997), the characteristic time for mass transfer can exceed 20 min for coarse particles.

$$
J_{i}=\frac{1}{\tau_{i}}\left(G_{i}-G_{i}^{e q}\right)
$$

$J_{i}\left(\mu \mathrm{g} \mathrm{m}^{-2} \mathrm{~s}^{-1}\right)$ is the absorption or desorption flux of species $i, \tau_{i}(s)$ is a characteristic time of the mass transfer that depends on particle size and the chemical properties of species $i, G_{i}$ is the bulk gas-phase concentration of species $i$ and $G_{i}^{e q}$ is the gasphase concentration of species $i$ at thermodynamic equilibrium (i.e., at the surface of the particle). The equilibrium gas-phase concentrations are functions of the particle chemical composition, temperature and, for hydrophilic species, relative humidity, as described in Pun et al. (2006).

The base SOA module was tested against smog chamber data (Odum et al. 1997) for anthropogenic compounds and for biogenic compounds (Griffin et al. 1999) and was shown to satisfactorily reproduce SOA formation for those compounds (Pun et al. 2006). In this study, higher alkanes and isoprene were added to the original chemical mechanism. The formation of SOA from higher alkanes follows the formulation used in Zhang et al. (2007) for the stoichiometric SOA yield and it is assumed that the SOA species can be represented by a hydrophobic surrogate compound with a moderate saturation vapor pressure. The formation of SOA from the oxidation of isoprene by hydroxyl radicals is represented with two surrogate products and follows the formulation prescribed in Kroll et al. (2006); Zhang et al. (2007). 
The previous biogenic inventory used in CHIMERE was based on Simpson's algorithms (Simpson et al. 1995; Moukhtar et al. 2005). Forests were assumed to have a uniform tree distribution within each country. Moreover, the gas emission potentials proposed in Simpson et al. (1995) are based on branch scale measurements only. Here, the new MEGAN model (Guenther et al. 2006, v. 2.04) is implemented, it exploits most recent measurements by combining gridded and canopy scale approaches, that are more appropriate for use in CTMs since they estimate the effective burden of gases that mix and react in the boundary layer. Estimates of biogenic VOCs from vegetation and $\mathrm{NO}$ emissions are calculated as:

$$
E R_{i}=E F_{i} \times \gamma_{i}(T, P P F D, L A I) \times \rho_{i}
$$

where $E R_{i}\left(\mu g m^{-2} h^{-1}\right)$ is the emission rate of species $i, E F_{i}\left(\mu g m^{-2} h^{-1}\right)$ is an emission factor at canopy standard conditions, $\gamma_{i}$ (unitless) is an emission activity factor that accounts for deviations from canopy standard conditions, and $\rho_{i}$ is a factor that accounts for production/loss within canopy. The canopy standard conditions relevant for this study are defined as: air temperature (T) of $303 \mathrm{~K}$, photosynthetic photon flux density (PPFD) of $1500 \mu \mathrm{mol} \mathrm{m} \mathrm{m}^{-2} \mathrm{~s}^{-1}$ at the top of the canopy, leaf area index (LAI) of $5 \mathrm{~m}^{2} \mathrm{~m}^{-2}$ and a canopy with $80 \%$ mature, $10 \%$ growing and $10 \%$ old foliage. The MEGAN model parameterizes the bulk effect of changing environmental conditions using three time-dependent input variables specified at top of the canopy: temperature (T), radiation (PPFD), and foliage density (LAI). The production/loss term within canopy is assumed to be unity $(\rho=1)$. The equation can then be expanded as:

$$
E R_{i}=E F_{i} \times \gamma_{T, i} \times \gamma_{P P F D} \times \gamma_{L A I}
$$

The MEGAN model provides input EF and LAI data over a global grid, herefater projected on the CHIMERE model grid. The current available choice for EFs is restricted to following species: isoprene, $\alpha$-pinene, $\beta$-pinene, myrcene, sabinene, limonene, $\delta^{3}$-carene, ocimene, and nitrogen oxide. Sesquiterpene emissions are not calculated. EF's are static and refer to years 2000-2001. They are obtained summing up over several plant functional types (e.g. broadleaf and needle trees, shrubs, etc...). LAI database is given as a monthly mean product derived from MODIS observations, referred to base year 2000. Hourly emissions are calculated using 2-m temperature and short-wave radiation from MM5 model. The optimal choice for this work is the 150" resolution product proposed in the MEGAN inventory.

Figure 2 shows the differences for August 2003 between the new inventory MEGAN implemented in CHIMERE and the former approach based on the Simpson's algorithms (Simpson et al. 1995). Large differences everywhere in Europe are observed for monoterpene emissions with lower emissions using the MEGAN algorithms. The differences are consistent to what recently reported in Arneth et al. (2008) and represent the uncertainty related to BVOC emission calculations in current models. Isoprene emissions are higher with MEGAN in Poland, Spain, Italy and Portugal and lower in Greece, United Kingdom and North Africa. 
(a) Total Monoterpenes (former algorithm)

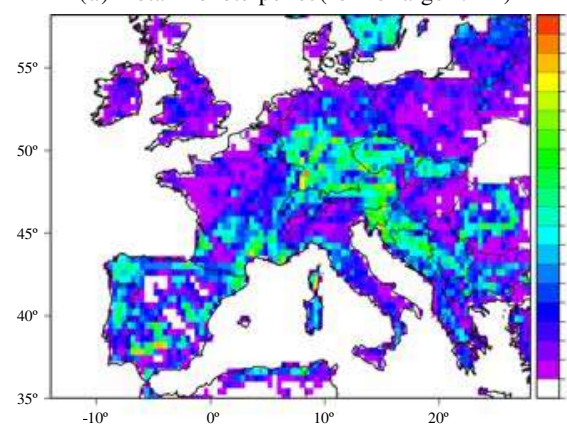

(c) Isoprene (former algorithm)

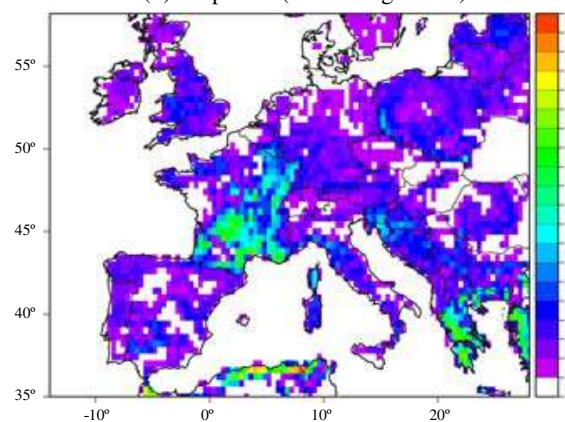

(b) Total Monoterpenes(MEGAN)

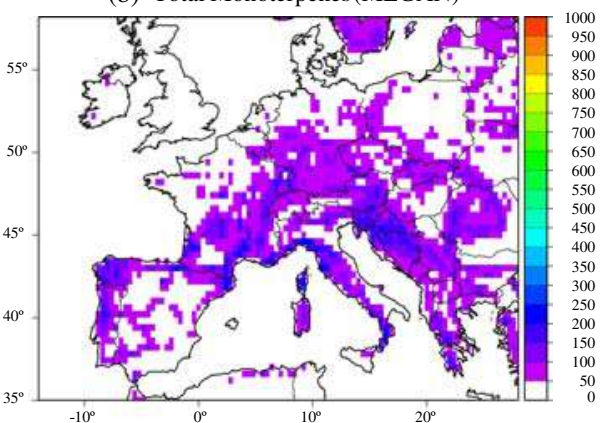

(d) Isoprene (MEGAN)

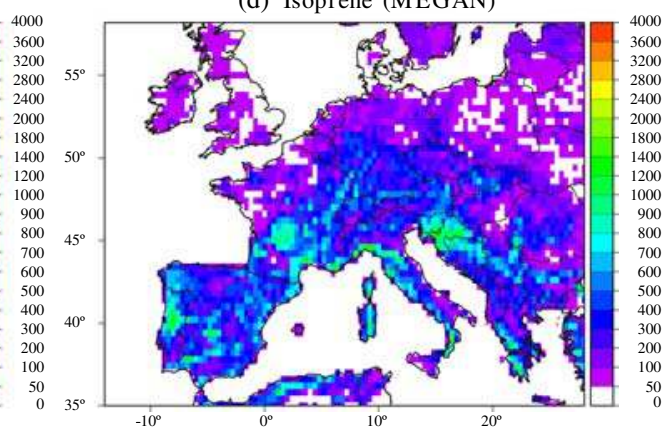

Fig. 2 Biogenic emissions (monoterpenes and isoprene) for August 2003 (in $\mathrm{kg} \mathrm{km}^{-2}$ ) calculated with the former algorithm in CHIMERE and the new MEGAN inventory (a-d)

\section{Model results and comparisons with observational data}

\subsection{Observational data}

Three kind of observation databases are used in this study.

(1) The CARBOSOL database as described in Pio et al. (2007); Legrand and Puxbaum (2007) provides EC, OC observations available on a weekly basis, about 50 samples per site were analyzed. Chemical analyses are made for particles smaller than and equal to $2.5 \mu \mathrm{m}$.

(2) The dataset issued from the EMEP 2002-2003 campaign provides a daily sample per week with only EC and OC analyses (Yttri et al. 2007) (about 25 samples per site). Analyses on particles smaller than and equal to $10 \mu m$ were performed using the thermal-optical transmission (TOT) instrument from Sunset Lab Inc., operating according to a NIOSH derived temperature program, more details can be found in Yttri et al. (2007).

(3) The routine measurements at the EMEP sites (http://www.emep.int) provide daily average $\mathrm{PM}_{10}$ concentrations (particle diameter smaller than and equal to $10 \mu \mathrm{m})$. To get a site in a french forestry region the station list is completed with the specific site of Périgueux managed by the french air quality network. 
The coordinates and locations in Europe of all stations used in this study are described in Table 2 and Fig. 3. For the model-to-data comparisons, concentrations are taken in the first model layer. This may induce representativity problems when the topography greatly varies from cells to cells as in mountainous regions. In order to convert the organic material $(\mathrm{OM})$ concentrations to the modeled organic carbon (OC), the relation proposed in Turpin and Lim (2001) was used with $O M=$ $1.6 \times O C$. SOA is a fraction of OM, the term SOA-C frequently used in the paper

Table 2 Names and coordinates of stations

\begin{tabular}{|c|c|c|c|c|}
\hline Station & Country & Lat. $\left({ }^{o} \mathrm{~N}\right)$ & Long. $\left({ }^{o} \mathrm{E}\right)$ & Altitude $(\mathrm{m})$ \\
\hline Puy de Dôme (PDD $\left.{ }^{\mathrm{a}}\right)$ & France & 45.45 & 3.00 & 1450 \\
\hline Périgueux $\left(\right.$ PERI $\left.^{\mathrm{d}}\right)$ & France & 45.19 & 0.73 & $\approx 100$ \\
\hline K-Puszta $\left(K^{\prime} Z^{a}\right)$ & Hungary & 46.97 & 19.58 & 125 \\
\hline Mace Head (IE31 $\left.{ }^{b, c}\right)$ & Irland & 53.33 & -9.90 & 25 \\
\hline Kollumerwaard (NL09 $9^{\mathrm{b}, \mathrm{c}}$ ) & The Netherlands & 53.33 & 6.28 & 0 \\
\hline Payerne $\left(\mathrm{CH} 02^{\mathrm{c}}\right)$ & Switzerland & 46.82 & 6.95 & 489 \\
\hline Tänikon $\left(\mathrm{CH} 03^{c}\right)$ & Switzerland & 47.48 & 8.90 & 539 \\
\hline Langenbrügge (DE02 $\left.{ }^{\mathrm{b}, \mathrm{c}}\right)$ & Germany & 52.80 & 10.76 & 74 \\
\hline Neuglobsow $\left(\mathrm{DE} 07^{\mathrm{c}}\right)$ & Germany & 53.17 & 13.03 & 62 \\
\hline Schmücke $\left(\mathrm{DE} 08^{\mathrm{c}}\right)$ & Germany & 50.65 & 10.77 & 937 \\
\hline Zingst (DE09' $)$ & Germany & 54.43 & 12.73 & 1 \\
\hline Schauinsland (SIL $\left.{ }^{\mathrm{a}}\right)$ & Germany & 47.92 & 7.90 & 1205 \\
\hline Košetice $\left(\mathrm{CZO3}^{\mathrm{b}, \mathrm{c}}\right)$ & The Czech Republic & 49.58 & 15.08 & 534 \\
\hline Stara Lesna $\left(\mathrm{SK} 04^{\mathrm{b}, \mathrm{c}}\right)$ & Slovakia & 49.15 & 20.28 & 808 \\
\hline Liesek $\left(\mathrm{SK} 05^{\mathrm{c}}\right)$ & Slovakia & 49.37 & 19.68 & 892 \\
\hline Starina $\left(\mathrm{SK} 06^{\mathfrak{c}}\right)$ & Slovakia & 49.05 & 22.27 & 345 \\
\hline Illmitz (AT02 $\left.2^{\mathrm{b}, \mathrm{c}}\right)$ & Austria & 47.77 & 16.77 & 117 \\
\hline St. Koloman (AT04 $\left.{ }^{\mathfrak{c}}\right)$ & Austria & 47.65 & 13.20 & 851 \\
\hline Montelibretti (IT01 $\left.{ }^{\mathrm{c}}\right)$ & Italy & 42.10 & 12.63 & 48 \\
\hline Ispra $\left(\mathrm{IT} 04^{\mathrm{b}, \mathrm{c}}\right)$ & Italy & 45.80 & 8.63 & 209 \\
\hline San Pietro Capofiume (IT08 ${ }^{\mathrm{b}}$ ) & Italy & 44.48 & 11.33 & $\approx 10$ \\
\hline Braganca $\left(\mathrm{PT} 01^{\mathrm{b}, \mathrm{c}}\right)$ & Portugal & 41.82 & -6.77 & 691 \\
\hline Aveiro $\left(\mathrm{AVE}^{\mathrm{a}}\right)$ & Portugal & 40.57 & -8.63 & 48 \\
\hline Penicuick (GB46 ${ }^{\mathrm{b}}$ ) & Great Brittain & 55.95 & -3.22 & $\approx 180$ \\
\hline Ghent $\left(\mathrm{BE} 02^{\mathrm{b}}\right)$ & Belgium & 51.05 & 3.72 & $\approx 10$ \\
\hline Keldsnor (DK05') & Denmark & 54.73 & 10.73 & 9 \\
\hline Niembro $\left(\mathrm{ES} 08^{\mathrm{c}}\right)$ & Spain & 43.44 & -4.85 & 134 \\
\hline Cabo de Creus $\left(\mathrm{ES} 10^{\mathrm{c}}\right)$ & Spain & 42.32 & 3.32 & 23 \\
\hline Barcarrota $\left(\mathrm{ES}_{11}{ }^{\mathrm{c}}\right)$ & Spain & 38.47 & -6.92 & 393 \\
\hline Zarra $\left(\mathrm{ES} 12^{\mathrm{c}}\right)$ & Spain & 39.09 & -1.10 & 885 \\
\hline Penausende $\left(\mathrm{ES} 13^{\mathrm{c}}\right)$ & Spain & 41.28 & -5.87 & 985 \\
\hline Els Torms $\left(\mathrm{ES} 14^{\mathrm{c}}\right)$ & Spain & 41.40 & 0.72 & 470 \\
\hline O Saviñao $\left(\mathrm{ES} 16^{\mathrm{c}}\right)$ & Spain & 43.23 & -7.70 & 506 \\
\hline Iskrba $\left(\mathrm{SI} 08^{\mathrm{c}}\right)$ & Slovenia & 45.57 & 14.87 & 520 \\
\hline
\end{tabular}

Most of the stations are rural background sites, except IT08, BE02 and PERI that are urban background sites

${ }^{\mathrm{a} C A R B O S O L}$ sites (EC,OC)

${ }^{b}$ EMEP sites of the EC/OC EMEP campaign

${ }^{\mathrm{c}}$ Routine EMEP sites $\left(\mathrm{PM}_{10}\right.$ data)

${ }^{\mathrm{d}}$ Station from the french monitoring network 


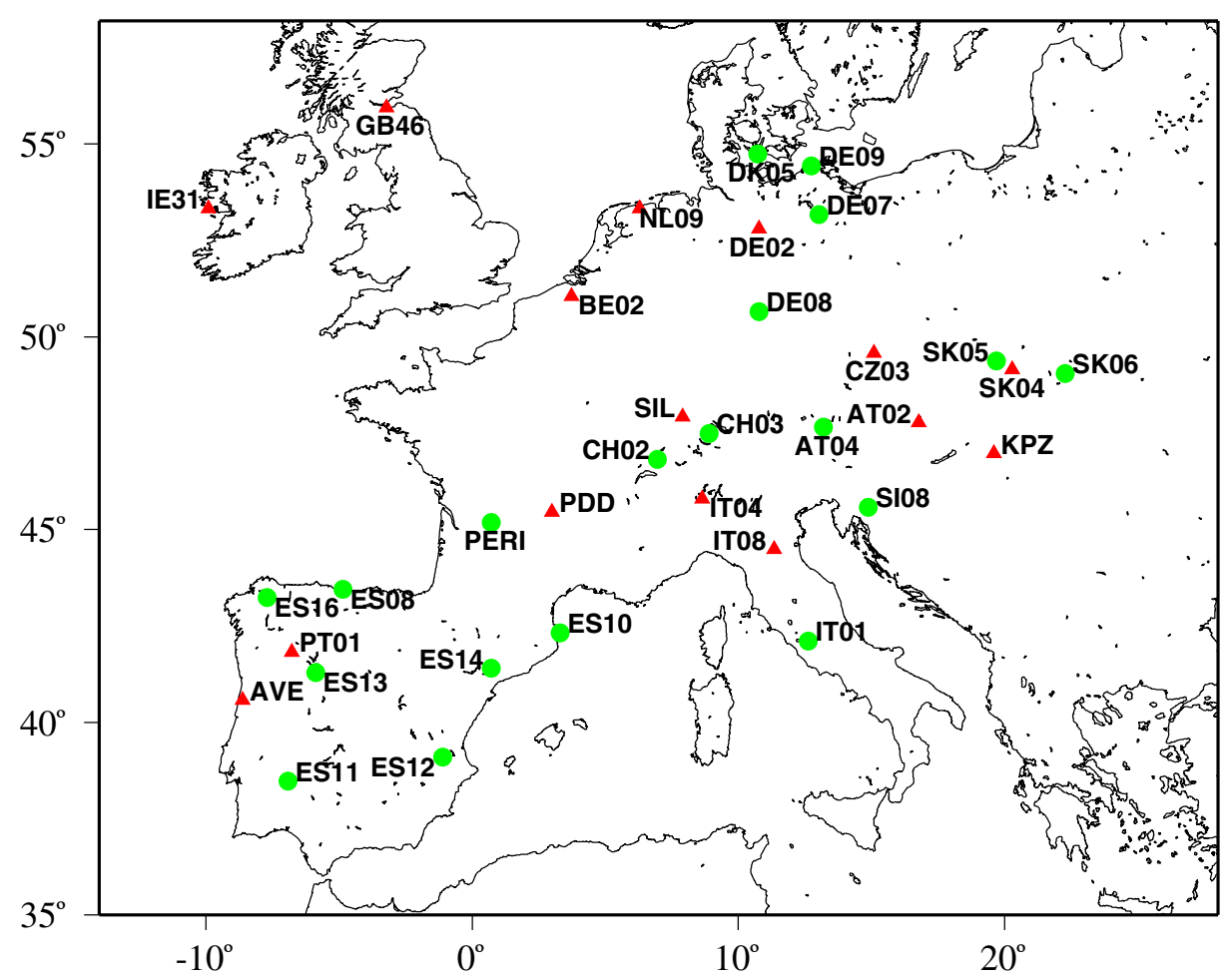

Fig. 3 Location of stations-Red triangles: OC and EC available measurements-Green circles: $\mathrm{PM}_{10}$ measurements available only. For IT04, SK04, AT02 sites both PM 10 and OC, EC measurements are available (see Table 2 for the name of stations and coordinates)

refers to the carbon in the secondary organic aerosols (SOA-C), the same coefficient is used for the conversion: $S O A=1.6 \times S O A-C$.

\subsection{SOA results and OC comparisons}

In Fig. 4 and Table 3, the comparison of CHIMERE with OC measurements shows a systematic underestimation at each site. Time correlations for PDD, SIL, BE02, GB46 and IE31 are in the range 0.75-0.91. For IT04, IT08, AVE, PT01, SK04 and KPZ sites a clear underestimation by the CHIMERE model is noticed in wintertime. The same underestimation by the EMEP model (Simpson et al. 2007) was attributed to missing wood burning sources in these countries. A smaller underestimation is observed at the other low altitude sites (DE02, AT02, CZ03, and NL09) for the same reasons. In summertime, SOA-C largely dominate the carbon fraction in model results, in the range $90-95 \%$ for the two elevated sites PDD (France) and SIL (Germany). CHIMERE gives surprisingly high SOA-C contributions to total OC concentrations in winter for PDD, 71\% and SIL, 52\% for January-March and October-December periods. These findings are consistent with other CARBOSOL's findings (Gelencsér et al. 2007) where high fractions of biogenic secondary organic carbon in winter, $72 \%$ at SIL and $69 \%$ at PDD, were reported. Moreover, within 

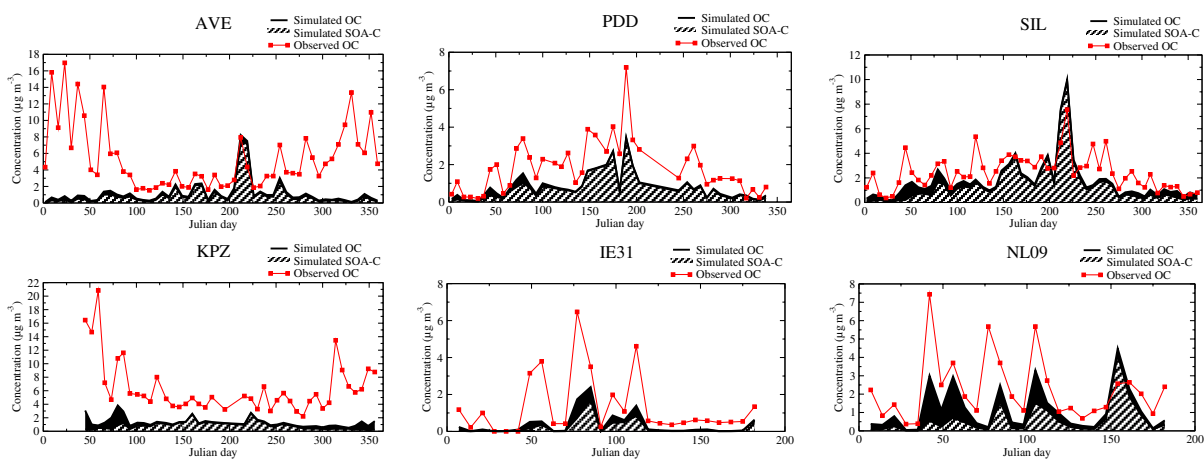

DE02
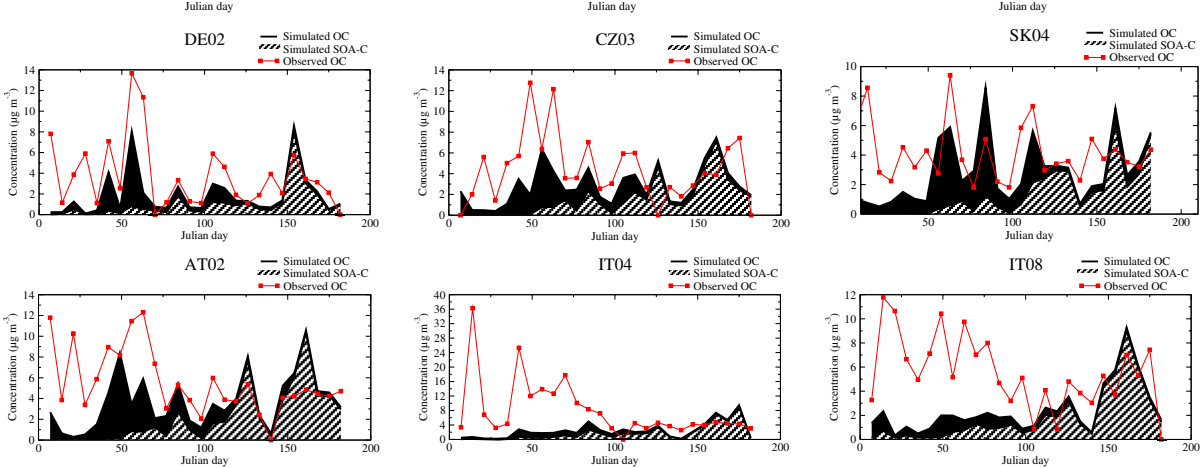

GB46 $\quad-$ Simulated OC
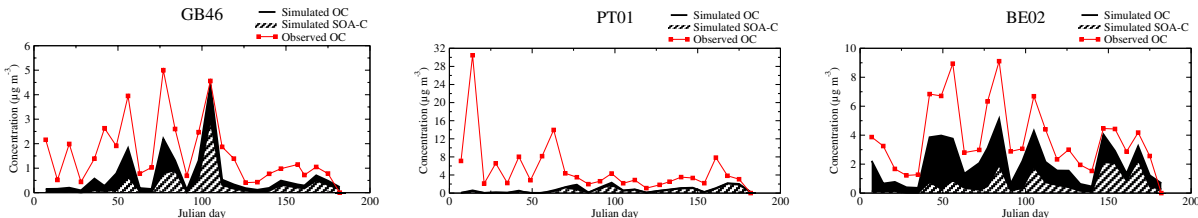

Fig. 4 Comparisons between observed (red squares) and simulated OC concentrations (filled area) in 2003 for the CARBOSOL and EC/OC EMEP campaign datasets. Carbon in the secondary organic aerosols $(\mathrm{SOA}-\mathrm{C})$ is represented by crosshatched area. The date corresponds to the first day of sampling (see the full names and locations of each site in Table 2 and Fig. 3)

the CARBOSOL framework at least $86 \%$ of OC was attributed to SOA-C during summer (Gelencsér et al. 2007).

The yearly average SOA concentrations (Fig. 5) range in most of the regions from $0.5 \mu \mathrm{g} \mathrm{m}^{-3}$ in the Northern Europe to $4 \mu \mathrm{g} \mathrm{m} \mathrm{m}^{-3}$ over forested regions (Black Forest, Portugal Forests, Massif-Central) and in the Pô valley, and peaking up to $6 \mu \mathrm{g} \mathrm{m}^{-3}$ in Croatia. These values are twice larger compared to those obtained by global model simulations $\left(3.75^{\circ} \times 5^{\circ}\right)$ (Tsikaridis and Kanakidou 2007), the dilution of emissions in larger grid cells can explain these differences. Nevertheless, the spatial pattern is very similar with a maximum from the Pô valley to the Eastern Europe. The yearly averaged contribution (ratio in \%) of secondary organic aerosols to the total organic material calculated by CHIMERE is mostly in the range $30-80 \%$ in Europe (Fig. 6). The highest ratios are found over the Pyrénées and Massif Central and in Spain. Poland displays lower SOA contributions in Europe because of higher primary organic emissions from industries in this country as previously discussed. 
Table 3 Model-to-data statistics for OC concentrations

\begin{tabular}{|c|c|c|c|c|c|c|c|c|c|c|}
\hline \multirow[t]{2}{*}{ Station } & \multirow[t]{2}{*}{ Obs. $^{1}$} & \multicolumn{3}{|c|}{ Total OC } & \multicolumn{3}{|c|}{$\begin{array}{l}\text { OC without } \\
\text { SOA-C }{ }^{c}\end{array}$} & \multicolumn{3}{|c|}{$\begin{array}{l}\text { OC without } \\
\text { isoprene SOA-C }\end{array}$} \\
\hline & & Mod. $^{2}$ & Corr. $^{3}$ & $\overline{\text { Err. }^{4}}$ & Mod. $^{2}$ & Corr. $^{3}$ & $\overline{\text { Err. }^{4}}$ & Mod. $^{2}$ & Corr. $^{3}$ & Err. $^{4}$ \\
\hline $\mathrm{AT} 02^{\mathrm{a}}$ & 5.82 & 3.86 & 0.11 & 46.30 & 1.61 & 0.55 & 73.83 & 2.78 & 0.40 & 48.62 \\
\hline $\mathrm{BE} 02^{\mathrm{a}}$ & 3.97 & 2.16 & 0.90 & 48.69 & 1.46 & 0.87 & 64.93 & 1.94 & 0.92 & 53.68 \\
\hline $\mathrm{CZO3}^{\mathrm{a}}$ & 4.98 & 2.84 & 0.33 & 48.79 & 1.36 & 0.51 & 73.55 & 2.23 & 0.47 & 52.10 \\
\hline $\mathrm{DE} 02^{\mathrm{a}}$ & 4.05 & 1.99 & 0.59 & 52.73 & 0.95 & 0.75 & 78.89 & 1.61 & 0.71 & 57.21 \\
\hline GB46 $6^{a}$ & 1.67 & 0.70 & 0.82 & 63.76 & 0.35 & 0.90 & 81.15 & 0.61 & 0.85 & 68.02 \\
\hline IE31 & 1.48 & 0.42 & 0.83 & 79.35 & 0.18 & 0.92 & 91.31 & 0.38 & 0.85 & 81.61 \\
\hline IT0 $4^{\mathrm{a}}$ & 8.30 & 2.49 & -0.11 & 69.36 & 0.72 & 0.52 & 90.09 & 1.60 & 0.10 & 72.69 \\
\hline IT08 ${ }^{\mathrm{a}}$ & 5.76 & 2.48 & 0.00 & 65.33 & 0.66 & 0.45 & 85.62 & 1.60 & 0.10 & 68.46 \\
\hline NL09 $9^{a}$ & 2.25 & 1.16 & 0.62 & 57.07 & 0.55 & 0.74 & 77.34 & 0.95 & 0.72 & 59.34 \\
\hline PT01 ${ }^{\mathrm{a}}$ & 5.30 & 0.80 & -0.08 & 77.43 & 0.14 & 0.05 & 96.23 & 0.51 & -0.02 & 85.52 \\
\hline SK04 ${ }^{a}$ & 4.16 & 2.89 & 0.29 & 50.32 & 1.54 & 0.33 & 72.69 & 2.24 & 0.35 & 57.82 \\
\hline $\mathrm{AVE}^{\mathrm{b}}$ & 5.43 & 1.16 & 0.01 & 74.10 & 0.23 & 0.41 & 94.59 & 0.73 & 0.11 & 82.19 \\
\hline $\mathrm{KPZ}^{\mathrm{b}}$ & 6.46 & 1.33 & 0.25 & 75.59 & 0.51 & 0.52 & 92.64 & 1.03 & 0.44 & 82.22 \\
\hline $\mathrm{PDD}^{\mathrm{b}}$ & 1.84 & 0.82 & 0.91 & 56.69 & 0.10 & 0.08 & 90.65 & 0.47 & 0.81 & 69.02 \\
\hline SIL $^{\mathrm{b}}$ & 2.47 & 1.74 & 0.75 & 39.82 & 0.32 & -0.06 & 80.94 & 1.16 & 0.73 & 49.22 \\
\hline
\end{tabular}

${ }^{1}$ Observation $\left(\mu g \mathrm{~m}^{-3}\right)$

${ }^{2}$ Model value $\left(\mu \mathrm{g} \mathrm{m}^{-3}\right)$

${ }^{3}$ Correlation factor

${ }^{4}$ Normalized error (\%)

${ }^{a}$ Daily average values for the EMEP campaign

${ }^{b}$ Weekly average values for the CARBOSOL campaign

${ }^{\mathrm{c}}$ Complete scheme with isoprene chemistry

${ }^{\mathrm{d}}$ Only monoterpene and anthropogenic VOCs chemistry with no isoprene chemistry

As shown in Fig. 7 the biogenic fraction of SOA dominates over continental areas exceeding $90 \%$ in a large area from Portugal to the North-East of France and over the Balkans. Over urbanized areas such as Paris and Milan only $20 \%$ of SOA is anthropogenic in origin, this is a direct consequence of the anthropogenic primary SVOCs chemistry not taken into account in this study. The current chemistry scheme with only primary VOC emissions are not able to produce large amounts of SOA. The fraction of secondary organic aerosols produced by isoprene chemistry ranges from $30 \%$ in Northern and Eastern Europe to 60\% in Spain (Fig. 8). These results are consistent with those reported in Tsikaridis and Kanakidou (2007) where a slightly lower range from the $20 \%$ to $50 \%$ over Europe with similar spatial patterns was related. High isoprene relative contributions are found over North Africa, but as shown in Fig. 5 total SOA concentrations are low in this region.

Regarding to studies over the United States, a study using a global model (Liao et al. 2007) reported a maximum concentration of $2 \mu \mathrm{g} \mathrm{m} \mathrm{m}^{-3}$ in summer with a contribution of $49.5 \%$ over the United States. By accounting for isoprene chemistry a large increase of the SOA global budget by a factor of two was reported in Henze and Seinfeld (2006).

The evaluation of a SOA scheme is difficult because total SOA measurements do not exist yet, only estimates will be soon available during specific campaigns. For the moment, only indirect evaluations can be carried out. Table 3 also displays how 


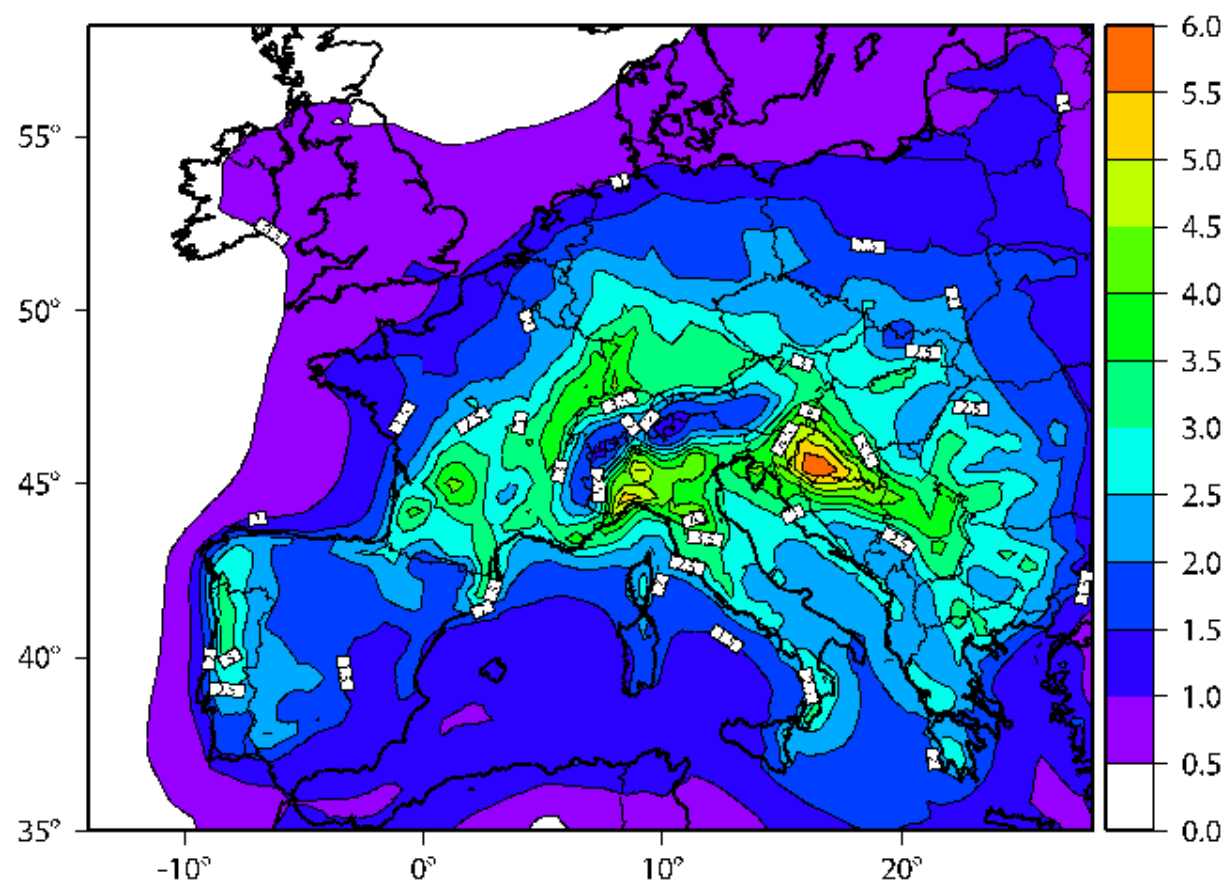

Fig. 5 Average SOA concentrations $\left(\mu \mathrm{g} \mathrm{m}^{-3}\right)$ in 2003 simulated by CHIMERE

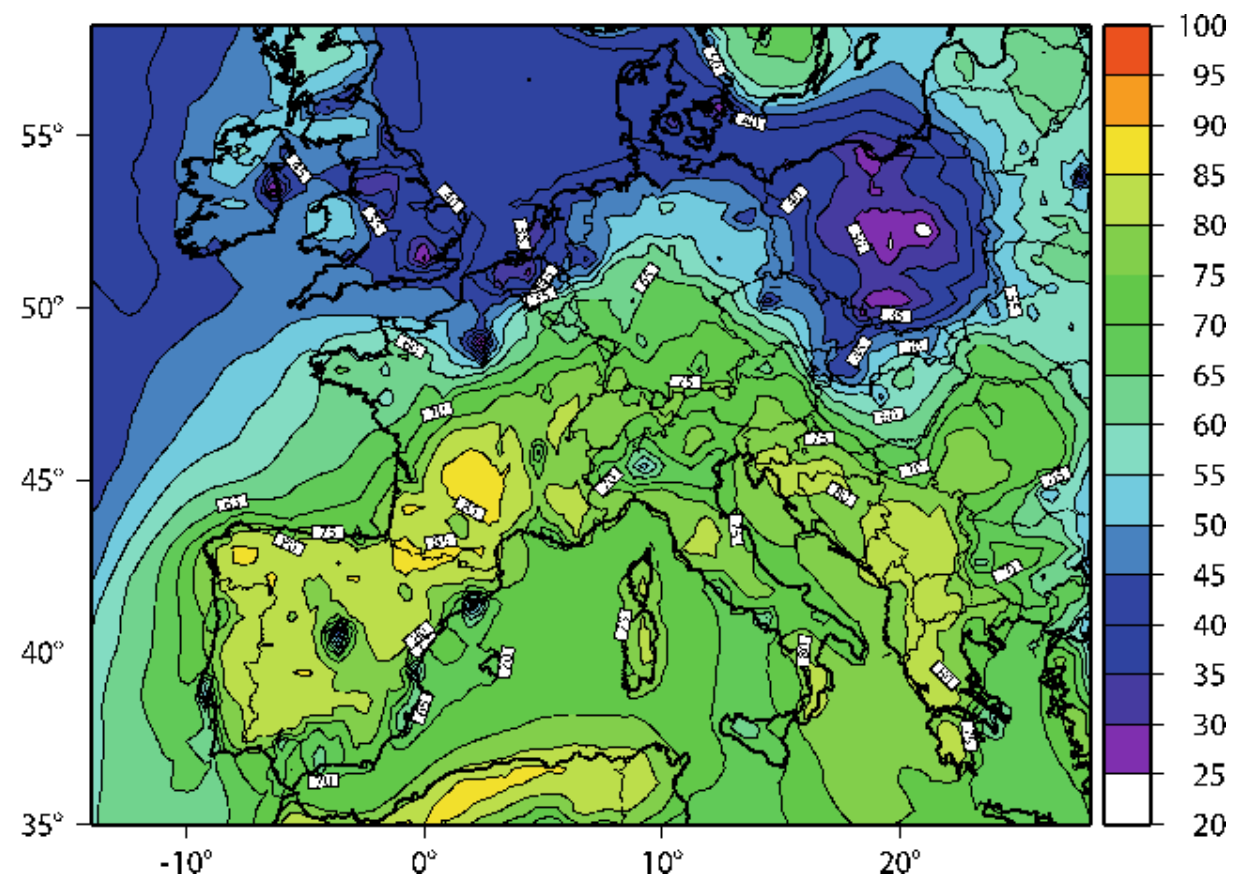

Fig. 6 Average contribution (\%) in 2003 of SOA to the total organic material calculated by CHIMERE 


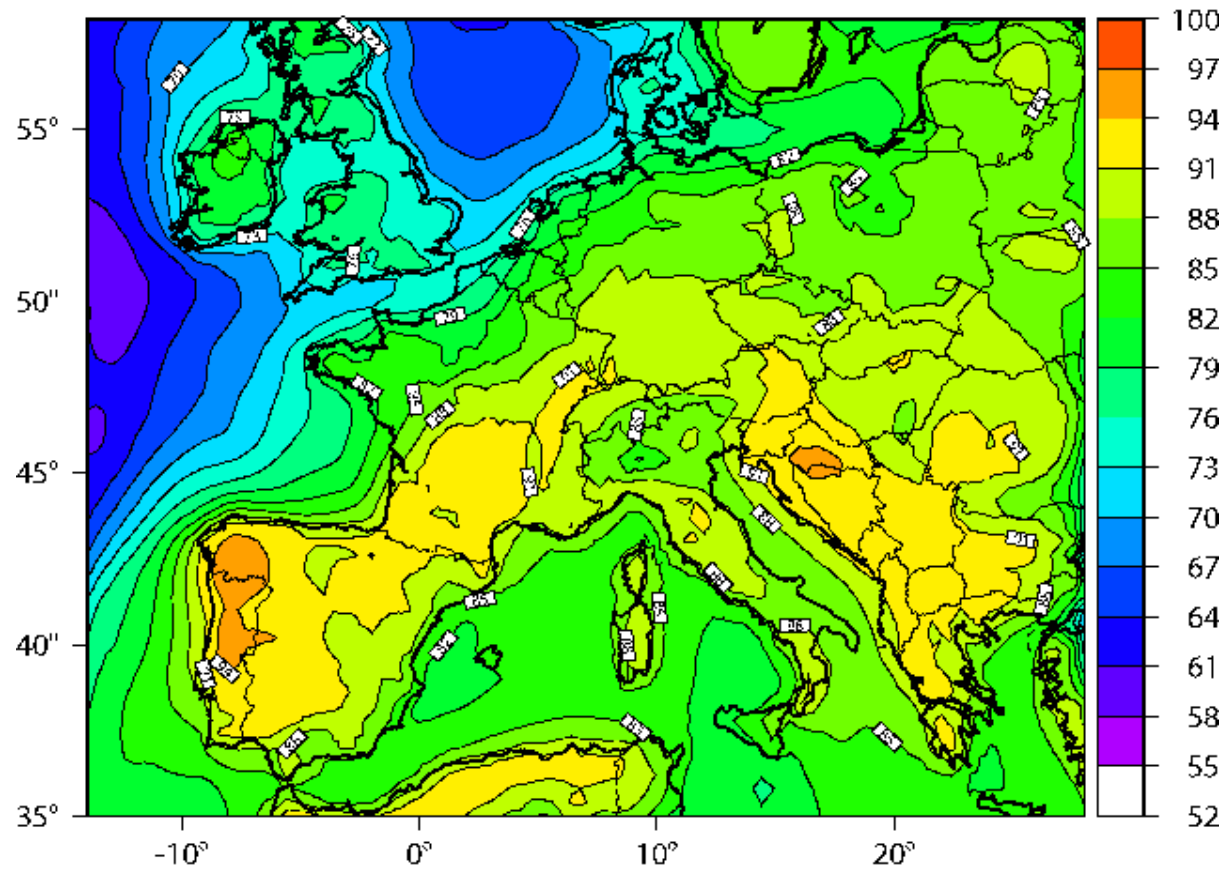

Fig. 7 Average contribution (\%) in 2003 of biogenic SOA to the total SOA calculated by CHIMERE

SOA chemistry acts on model OC performances. The normalized error is obviously reduced by adding SOA chemistry, particularly when the isoprene chemistry is implemented. These correlations are largely impaired at most of the sites, nevertheless, at the PDD and SIL sites during the CARBOSOL campaign the correlations are improved. The latter result makes sense, according to our biogenic emission inventory these sites are very close to biogenic emission sources. Moreover, these statistics are more representative because the CARBOSOL sites provide at least 50 samples for 2003 (versus about 25 for the EMEP campaign with only 3 to 4 data in summertime). In order to estimate the influence of SOA formation on PM concentrations, the impact of adding a SOA scheme has been evaluated on $\mathrm{PM}_{10}$ simulations. Several EMEP background sites in Europe have been selected with more than 300 samples per station.

As shown in Table 4, the implementation of the SOA scheme improves the time correlation at several background sites. Large improvements are observed in Spain and Slovenia where biogenic VOC emissions are very large. In Ispra (IT04), time correlations are impaired, but largely improved in Montelibretti (IT01). However, the correlation in IT01 was initially poor. This latter result is not significant compared to the slight decrease of correlation at IT04 particularly when adding SOA formed by isoprene. This shows model discrepancies for predicting biogenic SOA formation and particularly from isoprene in Italy and Slovakia. At DE08, a German station located in a forested region, a large improvement is also observed from 0.58 to 0.70. In Spain, a clear improvement is obtained by adding isoprene chemistry for 


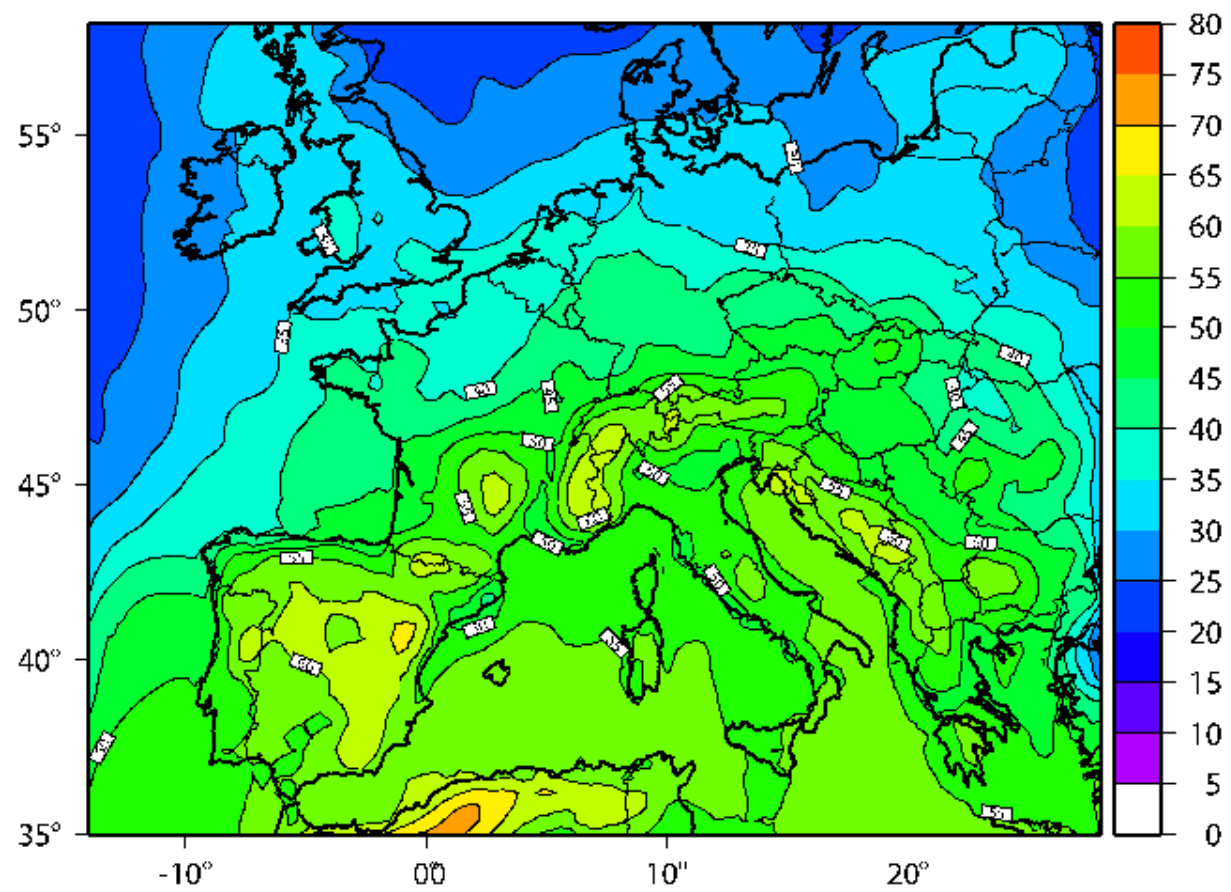

Fig. 8 Average contribution (\%) in 2003 of SOA from isoprene to the total SOA calculated by CHIMERE

SOA formation. In Slovakia, the time correlations are globally impaired. The urban site of Périgueux (PERI), a small city on the western part of the Massif Central, is located in a strong biogenic precursor emission area in France. In this region, the CHIMERE simulations exhibit a high contribution of secondary organic species (up to $80 \%$ ) to the total organic carbon, as shown in Fig. 6. The temporal correlation is largely improved from 0.39 to 0.51 at this site when implementing the SOA scheme. Considering only the summer period from May $1^{\text {st }}$ to September 30, the correlation is improved from 0.24 to 0.63 at Périgueux.

\subsection{EC comparisons}

Figure 9 and Table 5 display EC model results against observations for each site. As for OC concentrations, the model underpredicts EC concentrations at AVE, PT01, IT08, IT04 and KPZ particularly in winter. The assumption made in Simpson et al. (2007) about missing wood burning sources in the model could again explain this behavior. The model reproduces well the time evolution of EC concentrations at BE02, NL09, IE31 and GB46, these sites are very close to well documented sources and are located over flat areas. For Mace Head station (IE31), located along the Atlantic Ocean in Ireland, averaged EC concentrations given by the model are globally underestimated by a factor of two, $0.24 \mu \mathrm{g} \mathrm{m}^{-3} \mathrm{vs} .0 .13 \mu \mathrm{g} \mathrm{m}^{-3}$ respectively for the observations and the model. The associated time correlation is very high 0.89 , the model catches well the polluted air masses issued from the continent. The low 
Table 4 Impact of the SOA scheme implementation on the temporal correlation coefficients for $\mathrm{PM}_{10}$ concentrations observed and simulated

\begin{tabular}{|c|c|c|c|}
\hline Station & $\begin{array}{l}\text { Corr. without } \\
\text { SOA }\end{array}$ & $\begin{array}{l}\text { Corr. with SOA } \\
\left(\text { without isoprene } \mathrm{SOA}^{\mathrm{a}} \text { ) }\right.\end{array}$ & $\begin{array}{l}\text { Corr. with SOA } \\
\left(\text { with isoprene } \mathrm{SOA}^{\mathrm{b}}\right)\end{array}$ \\
\hline AT02 & 0.626 & 0.623 & 0.600 \\
\hline AT04 & 0.504 & 0.562 & 0.633 \\
\hline $\mathrm{CH} 02$ & 0.437 & 0.434 & 0.405 \\
\hline $\mathrm{CH} 03$ & 0.602 & 0.620 & 0.612 \\
\hline DE07 & 0.803 & 0.806 & 0.808 \\
\hline DE08 & 0.580 & 0.651 & 0.703 \\
\hline DE09 & 0.840 & 0.838 & 0.837 \\
\hline DK05 & 0.846 & 0.847 & 0.848 \\
\hline ES08 & 0.583 & 0.664 & 0.704 \\
\hline ES10 & 0.177 & 0.221 & 0.275 \\
\hline ES11 & 0.778 & 0.807 & 0.835 \\
\hline ES12 & 0.645 & 0.660 & 0.703 \\
\hline ES13 & 0.730 & 0.754 & 0.781 \\
\hline ES14 & 0.526 & 0.543 & 0.587 \\
\hline ES16 & 0.660 & 0.716 & 0.747 \\
\hline IT01 & 0.413 & 0.450 & 0.486 \\
\hline IT04 & 0.607 & 0.572 & 0.506 \\
\hline PERI & 0.391 & 0.488 & 0.512 \\
\hline SI08 & 0.427 & 0.469 & 0.503 \\
\hline SK04 & 0.440 & 0.454 & 0.458 \\
\hline SK05 & 0.441 & 0.416 & 0.365 \\
\hline SK06 & 0.435 & 0.412 & 0.353 \\
\hline
\end{tabular}

In bold, correlation coefficients improved by implementing the complete SOA scheme

${ }^{\mathrm{a}}$ Only monoterpene and anthropogenic VOCs chemistry

${ }^{\mathrm{b}}$ Complete scheme with isoprene chemistry

temporal correlation at the two elevated sites (SIL and PDD) suggests that these sites could be influenced by long range transport of anthropogenic pollution. As monthly climatologies are used at the domain boundaries, the model is not able to capture daily intercontinental fluxes that can influence EC concentrations at elevated sites. That could be the reason why correlations for OC concentrations are higher than those for EC concentrations at elevated sites because OC has a more local secondary origin than EC for SIL and PDD sites. As shown in Fig. 2 biogenic VOC emissions responsible for a major fraction of organic material are spread out over Europe compare to the spotty patterns of EC emissions. EC concentrations at remote places are affected by long range transport from anthropogenic emission areas (Kasper and Puxbaum 1998; Hitzenberger et al. 1999; Guillaume et al. 2008; Kaiser et al. 2007; Jaffe et al. 2003) and discrepancies in meteorological calculations can largely impair model concentrations. Indeed, even if the MM5 model has been already evaluated in others studies devoted to meteorological simulations, the transport process can explain such a behavior. Emissions are often located at low levels, because of cumulative errors in transport and mixing at such resolutions, it is not surprising to get such statistics on primary species at elevated sites. For gas phase chemistry, a similar behavior at remote background sites (Honoré et al. 2008) was already shown, with better correlations for ozone concentrations (secondary species) than for 

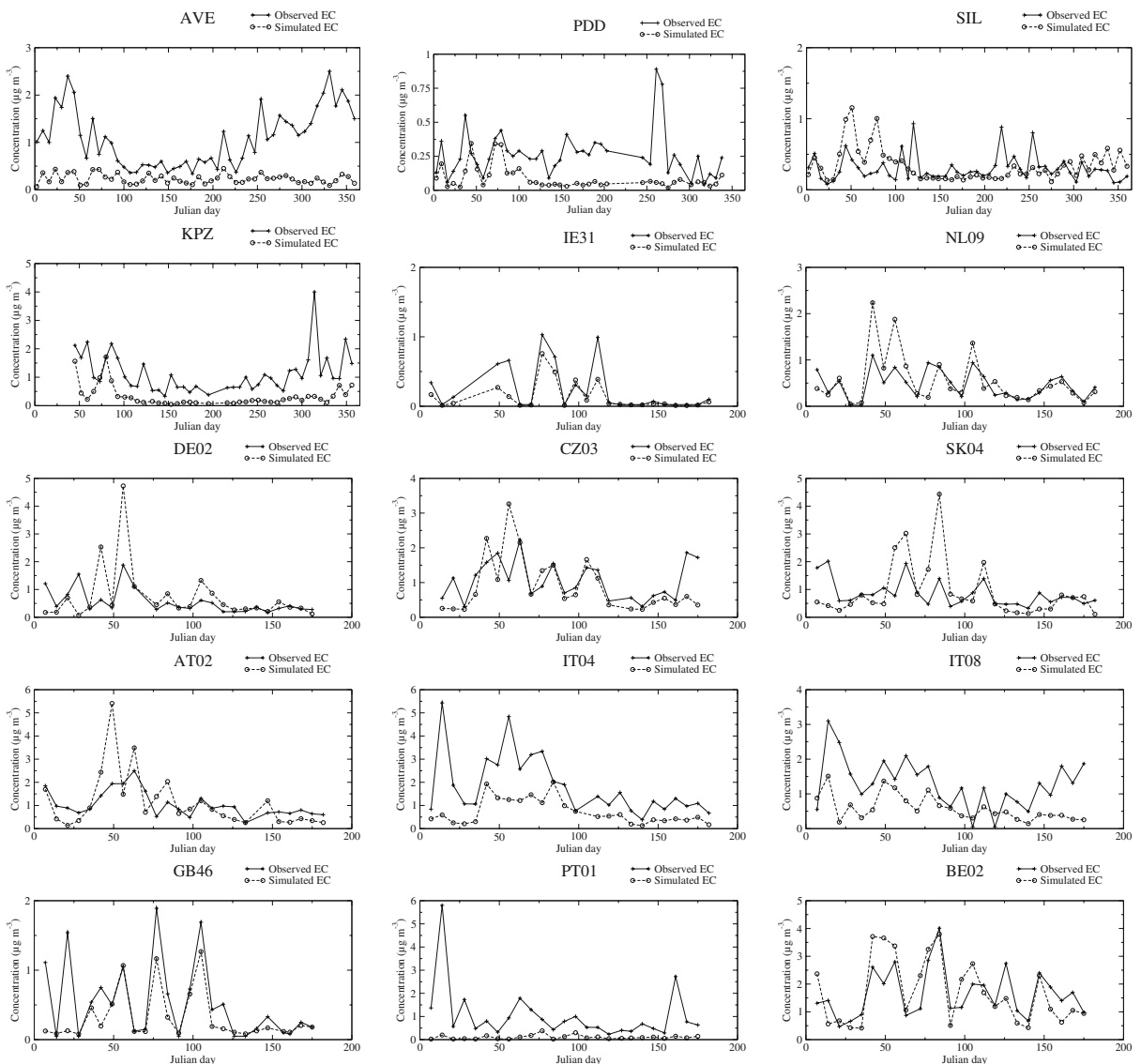

Fig. 9 Comparisons between observed (plus symbols) and simulated (circle symbols) EC concentrations in 2003 for the CARBOSOL and EC/OC EMEP campaign dataset. The date corresponds to the first day of sampling (see the full names and locations of each site in Table 2 and Fig. 3)

nitrogen oxides (primary species). Similarly, the previous analysis is consistent with the better correlations observed at some low altitude sites for EC concentrations model-to-data comparisons versus OC concentrations : AT02 (0.72 vs. 0.11), AVE (0.30 vs. 0.01), CZ03 (0.52 vs. 0.33), IT04 (0.58 vs. -0.11), IT08 (0.47 vs. 0.00) and NL09 (0.73 vs. 0.62). Indeed, the stations cited here before are mostly influenced by nearby emission areas : AT02 influenced by Vienna, AVE close to the industrial city of Aveiro, CZ03 influenced by industrial zone in the south of Poland, IT04 close to Milan, IT08 is an urban site and NL09 in the Netherlands is located within the most urbanized area in Europe.

\subsection{Mass distribution of SOA}

Mass distribution of aerosol species simulated by CHIMERE are shown in Fig. 10 for two background site PDD and NL09 the $1^{\text {st }}$ August 2003. For the most remote place (PDD), a peak of SOA is observed at $1 \mu \mathrm{m}$ with a non negligible amount in 
Table 5 Model-to-data statistics for EC concentrations

${ }^{1}$ Observation $\left(\mu g \mathrm{~m}^{-3}\right)$

${ }^{2}$ Model value $\left(\mu \mathrm{g} \mathrm{m}^{-3}\right)$

${ }^{3}$ Correlation factor

${ }^{4}$ Normalized error (\%)

${ }^{a}$ Daily average values for the

EMEP campaign

${ }^{\mathrm{b}}$ Weekly average values for the CARBOSOL campaign

\begin{tabular}{|c|c|c|c|c|}
\hline Station & Obs. ${ }^{1}$ & Mod. $^{2}$ & Corr. $^{3}$ & Err. $^{4}$ \\
\hline $\mathrm{AT} 02^{\mathrm{a}}$ & 1.04 & 1.12 & 0.72 & 55.2 \\
\hline $\mathrm{BE} 02^{\mathrm{a}}$ & 1.65 & 1.70 & 0.77 & 41.2 \\
\hline $\mathrm{CZO3}^{\mathrm{a}}$ & 1.05 & 0.90 & 0.52 & 42.3 \\
\hline $\mathrm{DE} 02^{\mathrm{a}}$ & 0.55 & 0.73 & 0.60 & 61.2 \\
\hline GB46 ${ }^{\mathrm{a}}$ & 0.52 & 0.31 & 0.75 & 44.3 \\
\hline IE31 & 0.24 & 0.13 & 0.89 & 41.1 \\
\hline IT04a & 1.83 & 0.72 & 0.58 & 58.6 \\
\hline IT08 & 1.29 & 0.58 & 0.47 & 100.9 \\
\hline $\mathrm{NLO9}^{\mathrm{a}}$ & 0.47 & 0.54 & 0.73 & 53.3 \\
\hline PT01 ${ }^{\mathrm{a}}$ & 1.03 & 0.11 & 0.30 & 86.0 \\
\hline $\mathrm{SK} 04^{\mathrm{a}}$ & 0.85 & 0.92 & 0.44 & 66.8 \\
\hline $\mathrm{AVE}^{\mathrm{b}}$ & 1.09 & 0.23 & 0.30 & 73.2 \\
\hline $\mathrm{KPZ}^{\mathrm{b}}$ & 1.14 & 0.33 & 0.40 & 72.2 \\
\hline $\mathrm{PDD}^{\mathrm{b}}$ & 0.26 & 0.09 & 0.23 & 63.5 \\
\hline $\mathrm{SIL}^{\mathrm{b}}$ & 0.30 & 0.34 & 0.17 & 69.1 \\
\hline
\end{tabular}

particles with diameter larger than $1 \mu \mathrm{m}$. For NL09 close to anthropogenic particle emission areas, the peak is located at 0.4-0.5 $\mu \mathrm{m}$. In our model, SOA are assumed to be absorbed into prexisting particles. The available surface for mass transfert and the absorbing mass drives the absorption process, so they absorb preferentially into fine particles. However, in very remote places, due to a lack of fine particles, those species can also absorb into coarse particles justifying our dynamical approach previously described.

\subsection{Potential impact of forest fires}

Fire emissions can be an important contributor to OC concentrations (Langmann et al. 2008). However, wild fire emissions do not contribute much to the atmospheric EC concentrations on a yearly average (Tsyro et al. 2007). The impact of fire
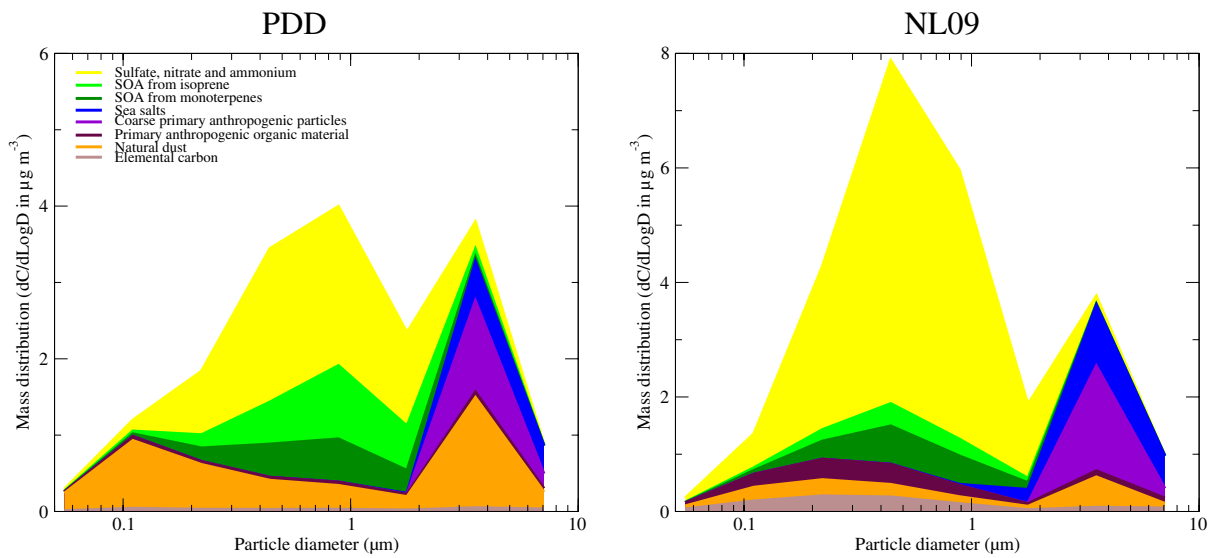

Fig. 10 Daily mean mass distribution of particle components the $1^{\text {st }}$ August 2003 at background stations NL09 and PDD simulated by CHIMERE 


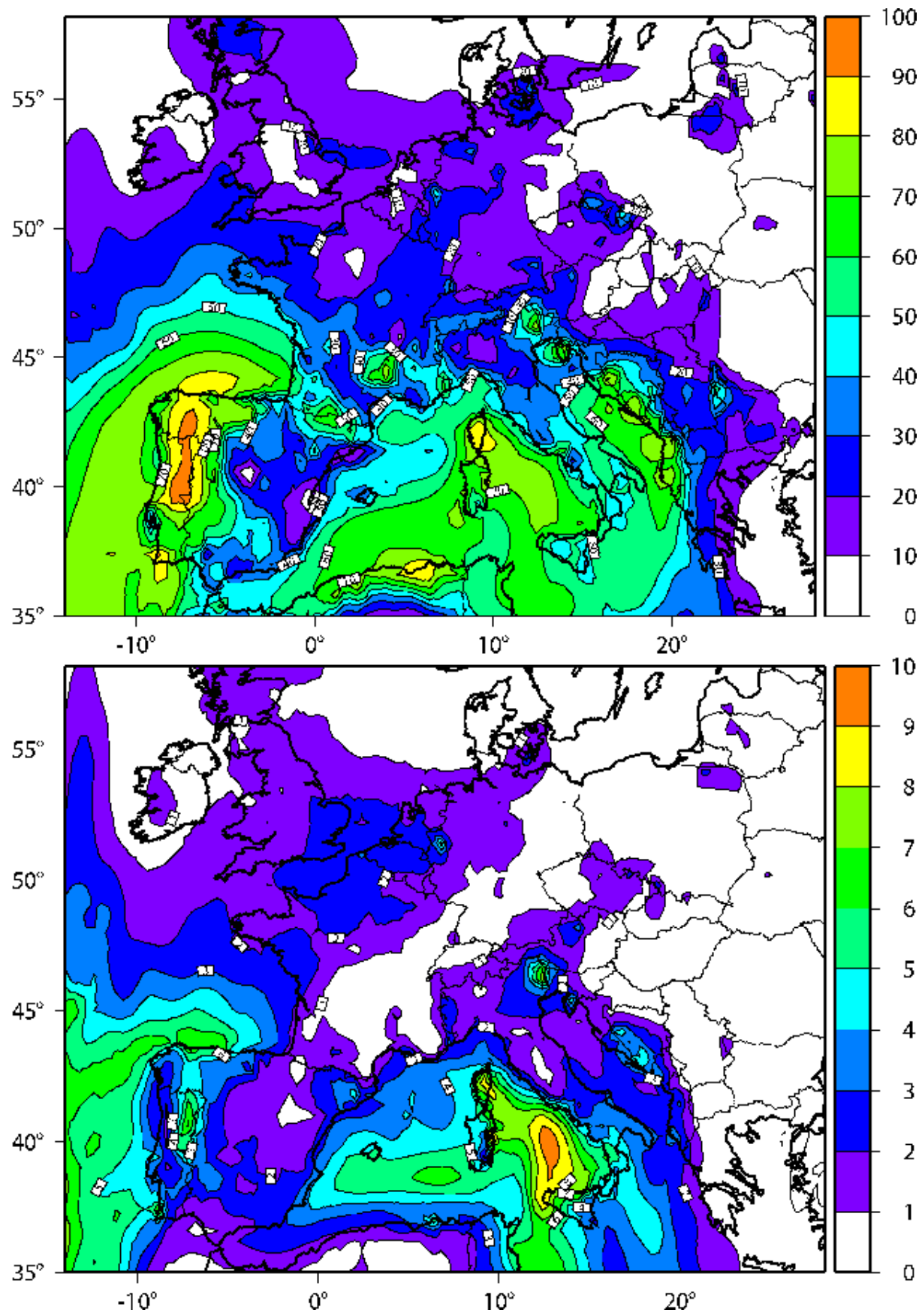

Fig. 11 Impact of forest fires (in \%) estimated by CHIMERE on August $1^{s t}-15,2003$. The figures display the ratio between (top) the primary OC concentrations from fires and total primary OC, and (bottom) the ratio between SOA concentrations from fires and total SOA 
emissions depends on fire buoyancy, and in models, sensitivity to fires depends on the altitude of their release on the vertical grid (Hodzic et al. 2006). Figure 11 shows the impact of adding forest fire emissions respectively on primary (a) and secondary organic material (b) estimated by CHIMERE on August $1^{s t}-15,2003$. During this period, intense fires were recorded around the Mediterranean basin and in Portugal. CHIMERE estimates give a large contribution of these fires to the primary organic concentrations in the South West of Europe with more than $90 \%$ in Portugal and often more than $50 \%$ over the Mediterranean Sea (Fig. 11a). Moreover, wildfires emit volatile organic precursors that can be oxidized to form SOA. In Fig. 11b, model results show a limited impact on the total SOA load of secondary organic material originating from biomass burning related to VOCs, less than $10 \%$ during the more intense fire period in August 2003. This modeling results provide a response to a key question concerning the relative contribution of secondary organic carbon from VOC emitted by vegetation and biomass burning (Gelencsér et al. 2007), because analysis methods cannot apportion the two contributions. This low contribution is mainly explained by the difference between VOC emissions from vegetation-1700 kTon-and wildfires-75 kTon-over our modeling domain in August 2003.

\section{Conclusion}

In order to better simulate the atmosphere composition, an improved secondary organic aerosols scheme was implemented in the CHIMERE chemistry-transport model. In parallel, the implementation of the MEGAN biogenic emissions inventory was performed. Accounting for these new contributions allowed an improvement of model results over the whole year of 2003 comparing with OC, EC and $\mathrm{PM}_{10}$ surface concentrations. Our work suggests that isoprene chemistry has a strong contribution to SOA concentrations in Europe and could explain large underestimation of OC concentrations in the southern Europe when this specific chemistry is not accounted for. Our findings are consistent with recent global model results and refine the spatial patterns of SOA concentrations in Europe. However, in this study, a clear underestimation of $\mathrm{OC}$ concentrations was diagnosed during winter. A possible explanation is that wood burning emissions in Portugal, Italy, Slovakia and Hungary are missing in the model emission inventory as suggested by a recent modeling work (Simpson et al. 2007) carried out with a different model and other input data (meteorology and emissions). Satisfactory correlations are noticed between model and observed OC at elevated sites such as Puy de Dôme (France) and Schauinsland (Germany) investigated during the CARBOSOL campaign. In these specific cases, the contribution of SOA to the total OC even in winter is quite high that is consistent with CARBOSOL's findings. For these two elevated sites, the implementation of a complete SOA scheme involving monoterpenes and isoprene chemistry clearly improves the predicted OC concentrations. However, adding SOA schemes impair correlation factors in Portugal, Italy and Slovakia. Those discrepancies with observational data could have several origins such as deficient biogenic emission inventories, meteorological data or SOA chemistry and physics. In addition, our work suggests that during the higher fire emission periods, OC concentrations from fires can be the 
major part of primary organic carbon. The contribution of SOA from fire emissions remains low.

Acknowledgements This work was funded by the French Ministry in charge of Ecology (MEEDDAT). We thank David Simpson (EMEP, Norway) for providing us the CARBOSOL data, CARBOSOL was financed by European Commission (EVK2-2001-113). Yann Martinet (CITEPA, France) is acknowledged for his contribution in emission speciation. We also thank Alex Guenther (NCAR, USA) for providing us the MEGAN biogenic inventory. G. Curci has been supported by EU/FP6 CIRCE project. We thank METEOCIEL (www.meteociel.com) for providing us the meteorological data.

\section{References}

Altieri, K.E., Seitzinger, S.P., Carlton, A.G., Turpin, B.J., Klein, G.C., Marshall, A.G.: Oligomers formed through in-cloud methylglyoxal reactions: chemical composition, properties, and mechanisms investigated by ultra-high resolution FT-ICR mass spectrometry. Atmos. Environ. 42, $1476-1490$ (2008)

Arneth, A., Monson, R.K., Schurgers, G., Niinemets, U., Palmer, P.I.: Why are estimates of global terrestrial isoprene emissions so similar (and why is this not so for monoterpenes)? Atmos. Chem. Phys. 8, 4605-4620 (2008)

Bauer, H., Kasper-Giebl, A., Löflund, M., Giebl, H., Hitzenberger, R., Zibuschka, F., Puxbaum, H.: The contribution of bacteria and fungal spores to the organic carbon content of cloud water, precipitation and aerosols. Atmos. Res. 64, 109-119 (2002)

Bessagnet, B., Hodzic, A., Vautard, R., Beekmann, M., Cheinet, S., Honoré, C., Liousse, C., Rouil, L.: Aerosol modeling with CHIMERE: preliminary evaluation at the continental scale. Atmos. Environ. 38, 2803-2817 (2004)

Bessagnet, B., Hodzic, A., Blanchard, O., Lattuati, M., Le Bihan, O., Marfaing, H., Rouiil, L.: Origin of particulate matter pollution episodes in wintertime over the Paris Basin. Atmos. Environ. 39, 6159-6174 (2005)

Black, E., Blackburn, M., Harrison, G., Hoskins, B., Methven, J.: Factors contributing to the summer 2003 European heatwave. Weather 59(8), 219-223 (2004)

Bond, T., Streets, D., Yarber, K., Nelson, S., Woo, J.H., Klimont, Z.: A technology-based global inventory of black and organic carbon emissions from combustion. J. Geophys. Res. 109, D14, 203 (2004). doi:10.1029/2003JD003697

Bonn, B., Moortgat, G.K.: New particle formation during $\alpha$ and $\beta$-pinene oxidation by $\mathrm{O} 3, \mathrm{OH}$ and NO3, and the influence of water vapour: particle size distribution studies. Atmos. Chem. Phys. 2 , 183-196 (2002)

Bowman, F.m., Odum, J.R., Seinfeld, J.H., Pandis, S.N.: Mathematical model for gas-particle parttioning of secondary organic aerosols. Atmos. Environ. 31, 3921-3931 (1997)

Dentener, F., Kinne, S., Bond, T., Boucher, O., Cofala, J., Generoso, S., Ginoux, P., Gong, S., Hoelzemann, J., Ito, A., Marelli, L., Penner, J., Putaud, J.P., Textor, C., Schulz, M., Werf, G.v.d., Wilson, J.: Emissions of primary aerosol and precursor gases in the years 2000 and 1750 prescribed data-sets for AeroCom. Atmos. Chem. Phys. 6, 4321-4344 (2006)

Dommen, J., Metzger, A., Duplissy, J., Kalberer, M., Alfarra, M.R., Gascho, A., Weingartner, E., Prevot, A.S.H., Verheggen, B., Baltensperger, U.: Laboratory observation of oligomers in the aerosol from isoprene/ $\mathrm{NO}_{x}$ photooxidation. Geophys. Res. Lett. 33, L13805 (2006). doi:10.1029/2006GL026523

Donahue, N.M., Robinson, A.L., Stanier, C.O., Pandis, S.N.: Coupled partitioning, dilution, and chemical aging of semivolatile organics. Environ. Sci. Technol. 40, 2635-2643 (2006). doi:10.1021/es052297

Dudhia, J.: A nonhydrostatic version of the Penn State/NCAR mesoscale model: validation tests and simulation of an Atlantic cyclone and cold front. Mon. Weather Rev. 121, 1493-1513 (1993)

EPA: Volatile Organic Compounds (VOC)/Particulate Matter (PM) Speciation Data System (SPECIATE), version 1.5, emission inventory branch (MD-14). Tech. Rep., Office of Air Quality Planning and Standards, U.S. Environmental Protection Agency, Research Triangle Park, NC (1993) 
Fan, J.W., Zhang, R.Y., Collins, D., Li, G.H.: Contribution of secondary condensable organics to new particle formation: a case study in Houston, Texas. Geophys. Res. Lett. 33, L15802 (2006). doi:10.1029/2006GL026295

Gelencsér, A., May, B., Simpson, D., Sánchez-Ochoa, A., Kasper-Giebl, A., Puxbaum, H., Caseiro, A., Pio, C., Legrand, M.: Source apportionment of PM2.5 organic aerosol over Europe: primary/secondary, natural/anthropogenic, and fossil/biogenic origin. J. Geophys. Res. 112, D23S04 (2007). doi:10.1029/2006JD008094

Graber, E.R., Rudich, Y.: Atmospheric HULIS: how humic-like are they? A comprehensive and critical review. Atmos. Chem. Phys. 6, 729-753 (2006)

Griffin, R.J., Cocker, E.R., Flagan, R.C., Seinfeld, J.H.: Organic aerosol formation from the oxidation of biogenic hydrocarbons. J. Geophys. Res. 104, 3555-3567 (1999)

Guenther, A., Karl, T., Harley, P., Wiedinmyer, C., Palmer, P.I., Geron, C.: Estimates of global terrestrial isoprene emissions using MEGAN (Model of Emissions of Gases and Aerosols from Nature). Atmos. Chem. Phys. 6, 3181-3210 (2006)

Guillaume, B., Liousse, C., Rosset, R., Cachier, H., Bessagnet, B., Velthoven, P.V., Poisson, N.: Global modelling of internally mixed size-resolved inorganic/organic aerosols with a focus on carbonaceous components. Tellus, B 9, 283-302 (2007)

Guillaume, B., Liousse, C., Galy-Lacaux, C., Rosset, R., Gardrat, E., Cachier, H., Bessagnet, B., Poisson, N.: Modeling exceptional high concentrations of carbonaceous aerosols observed at Pic du Midi in spring-summer 2003: comparison with Sonnblick and Puy de Dôme. Atmos. Environ. 42, 5140-5149 (2008)

Hansen, M., DeFries, R., Townshend, J., Sohlberg, R.: Global land cover classification at $1 \mathrm{~km}$ resolution using a decision tree classifier. Int. J. Remote Sens. 21, 1331-1365 (2000)

Heinrich, J., Slama, R.: Fine particles, a major threat to children. Int. J. Hyg. Environ. Health 210, 617-622 (2007)

Henze, D.K., Seinfeld, J.H.: Global secondary organic aerosol from isoprene oxidation. Geophys. Res. Lett. 33, L09812 (2006). doi:10.1029/2006GL025976

Hitzenberger, R., Berner, A., Giebl, H., Kromp, R., Larson, S.M., Rouc, A., Koch, A., Marischka, S., Puxbaum, H.: Contribution of carbonaceous material to cloud condensation nuclei concentrations in European background (Mt. Sonnblick) and urban (Vienna) aerosols. Atmos. Environ. 33(17), 2647-2659 (1999). ISSN 1352-2310, doi:10.1016/S1352-2310(98)00391-4

Hodzic, A., Madronich, S., Bohn, B., Massie, S., Menut, L., Wiedinmyer, C.: Wildfire particulate matter in Europe during summer 2003: meso-scale modeling of smoke emissions, transport and radiative effects. Atmos. Chem. Phys. 7, 4043-4064 (2007)

Hodzic, A., Vautard, R., Bessagnet, B., Lattuati, M., Moreto, F.: Long-term urban aerosol simulation versus routine particulate matter observations. Atmos. Environ. 39, 5851-5864 (2005)

Hodzic, A., Vautard, R., Chepfer, H., Goloub, P., Menut, L., Chazette, P., Deuze, J., Apituley, A., Couvert, P.: Evolution of aerosol optical thickness over Europe during the August 2003 heat wave as seen from CHIMERE model simulations and POLDER data. Atmos. Chem. Phys. 6, 1853-1864 (2006)

Hogrefe, C., Trivikrama Rao, S., Kasibhatla, P., Kallos, G., Tremback, C.J., Hao, W., Olerud, D., Xiu, A., McHenry, J., Alapaty, K.: Evaluating the performance of regional-scale photochemical modeling systems: part I - meteorological predictions. Atmos. Environ. 35, 4159-4174 (2001)

Holmes, N.S.: A review of particle formation events and growth in the atmosphere in the various environments and discussion of mechanistic implications. Atmos. Environ. 41, 2183-2201 (2007)

Honoré, C., Rouill, L., Vautard, R., Beekmann, M., Bessagnet, B., Dufour, A., Elichegaray, C., Flaud, J.M., Malherbe, L., Meleux, F., Menut, L., Martin, D., Peuch, A., Peuch, V.H., Poisson, N.: Predictability of European air quality: assessment of 3 years of operational forecasts and analyses by the PREV'AIR system. J. Geophys. Res. 113, D04301 (2008). doi:10.1029/2007JD008761

Hsieh, L.Y., Kuo, S.C., Chen, C.L., Tsai, Y.I.: Origin of low-molecular-weight dicarboxylic acids and their concentration and size distribution variation in suburban aerosol. Atmos. Environ. 41, 6648-6661 (2007)

Jaffe, D., McKendry, I., Anderson, T., Price, H.: Six new episodes of trans-pacific transport of air pollutants. Atmos. Environ. 37, 391-404 (2003)

Jaffrezo, J.L., Aymoz, G., Cozic, J.: Size distribution of EC and OC in the aerosol of Alpine valleys during summer and winter. Atmos. Chem. Phys. 5, 2915-2925 (2005)

Jiménez, P., Jorba, O., Parra, R., Baldasano, J.M.: Evaluation of MM5-EMICAT2000-CMAQ performance and sensitivity in complex terrain: high-resolution application to the northeastern Iberian Peninsula. Atmos. Environ. 40, 5056-5072 (2006) 
Junker, C., Liousse, C.: A global emission inventory of carbonaceous aerosol from historic records of fossil fuel and biofuel consumption for the period 1860-1997. Atmos. Chem. Phys. 8, 1195-1207 (2008)

Kaiser, A., Scheifinger, H., Spangl, W., Weiss, A., Gilge, S., Fricke, W., Ries, L., Cemas, D., Jesenovec, B.: Transport of nitrogen oxides, carbon monoxide and ozone to the Alpine Global Atmosphere Watch stations Jungfraujoch (Switzerland), Zugspitze and Hohenpeissenberg (Germany), Sonnblick (Austria) and Mt. Krvavec (Slovenia). Atmos. Environ. 41, 9273-9287 (2007)

Kasper, A., Puxbaum, H.: Seasonal variation of $\mathrm{SO}_{2}, \mathrm{HNO}_{3}, \mathrm{NH}_{3}$ and selected aerosol components at Sonnblick (3106 m a.s.l.). Atmos. Environ. 32(23), 3925-3939 (1998)

Kavouras, I., Mihalopoulos, N., Stephanou, E.: Formation of atmospheric particles from organic acids produced by forests. Nature 395, 683-686 (1998)

Kerminen, V.M., Teinilä, K., Hillamo, R., Mäkelä, T.: Size-segregated chemistry of particulate dicarboxylic acids in the Arctic atmosphere. Atmos. Environ. 33, 2089-2100 (1999)

Kleindienst, T.E., Jaoui, M., Lewandowski, M., Offenberg, J.H., Lewis, C.W., Bhave, P.V., Edney, E.O.: Estimates of the contributions of biogenic and anthropogenic hydrocarbons to secondary organic aerosol at a southeastern US location. Atmos. Environ. 41, 8288-8300 (2007)

Klimont, Z., Cofala, J., Bertok, I., Amann, M., Heyes, C., Gyarfas, F.: Estimating costs for controlling emissions of volatile organic compounds (VOC) from stationary sources in Europe. Tech. Rep., IIASA Interim Report IR-02-76., Laxenburg (2002)

Kroll, J.H., Ng, N.L., Murphy, S.M., Flagan, R.C., Seinfeld, J.H.: Secondary organic aerosol formation from isoprene photooxidation. Environ. Sci. Technol. 40, 1869-1877 (2006). doi: $10.1021 / \mathrm{es} 0524301$

Kroll, J.H., Seinfeld, J.H.: Review: chemistry of secondary organic aerosol: formation and evolution of low-volatility organics in the atmosphere. Atmos. Environ. 42, 3593-3624 (2008)

Langmann, B., Varghese, S., Marmer, E., Vignati, E., Wilson, J., Stier, P., O’Dowd, C.: Aerosol distribution over Europe: a model evaluation study with detailed aerosol microphysics. Atmos. Chem. Phys. 8, 1591-1607 (2008)

Lee, J.T., Son, J.Y., Cho, Y.S.: The adverse effects of fine particle air pollution on respiratory function in the elderly. Sci. Total Environ. 385, 28-36 (2007)

Legrand, M., Puxbaum, H.: Summary of the CARBOSOL project: present and retrospective state of organic versus inorganic aerosol over Europe. J. Geophys. Res. 112, D23S01 (2007). doi:10.1029/2006JD008271

Liao, H., Henze, D.K., Seinfeld, J.H., Wu, S., Mickley, L.J.: Biogenic secondary organic aerosol over the unites states: comparison of climatological simulations with observations. J. Geophys. Res. 112, D06,201 (2007). doi:10.1029/2006JD007813

Lukács, H., Gelencsér, A., Puxbaum, H., Pio, C., Legrand, M., Caseiro, A., Limbeck, A., Preunkert, S.: Seasonal trends and possible sources of brown carbon based on 2-year aerosol measurements at six sites in Europe. J. Geophys. Res. 112, D23S18 (2007). doi:10.1029/2006JD008151

Mayol-Bracero, O.L., Guyon, P., Graham, B., Roberts, G., Andreae, M.O., Decesari, S., Facchini, M.C., Fuzzi, S., Artaxo, P.: Water-soluble organic compounds in biomass burning aerosols over Amazonia 2. Apportionment of the chemical composition and importance of the polyacidic fraction. J. Geophys. Res. 107(D20), 8091 (2002). doi:10.1029/2001JD000522

Moukhtar, S., Bessagnet, B., Rouïl, L., Simon, V.: Monoterpene emissions from beech (fagus sylvatica) in a french forest and impact on secondary pollutants formation at regional scale. Atmos. Environ. 39, 3535-3547 (2005)

Nenes, A., Pilinis, C., Pandis, S.N.: ISORROPIA: a new thermodynamic equilibrium model for multiphase multicomponent marine aerosols. Aquat. Geochem. 4, 123-152 (1998)

Odum, J.R., Jungkamp, T.P.W., Griffin, R.J., Forstner, J.L., Flagan, R.C., Seinfeld, J.H.: Aromatics, reformulated gasoline and atmospheric organic aerosol formation. Environ. Sci. Technol. 31, 1890-1897 (1997)

Oliveira, C., Pio, C., Evtyugina, M., Santos, P., Gon scalves, V., Nunes, T., Silvestre, A.J.D., Palmgren, F., Wå hlin, P., Harrad, S.: Seasonal distribution of polar organic compounds in the urban atmosphere of two large cities from the north and south of Europe. Atmos. Environ. 41, 5555-5570 (2007)

Pankow, J.F.: An absorption model for gas/aerosol partition involved in the formation of secondary organic aerosol. Atmos. Environ. 28, 189-193 (1994)

Pio, C.A., Legrand, M., Oliveira, T., Afonso, J., Santos, C., Caseiro, A., Fialho, P., Barata, F., Sánchez-Ochoa, A., Kasper-Giebl, A., Gelencsér, A., Preunkert, S., Schock, M.: Climatology of 
aerosol composition (organic versus inorganic) at nonurban sites on a west-east transect across Europe. J. Geophys. Res. 112, D23S02 (2007). doi:10.1029/2006JD008038

Pun, B., Seigneur, C., Lohman, K.: Modeling secondary organic aerosol via multiphase partitioning with molecular data. Environ. Sci. Technol. 40, 4722-4731 (2006)

Pun, B., Seigneur, C.: Investigative modeling of new pathways for secondary organic aerosol formation. Atmos. Chem. Phys. 7, 2199-2216 (2007)

Putaud, J.P., Raes, F., Van Dingenen, R., Bruggemann, E., Facchini, M.C., Decesari, S., Fuzzi, S., Gehrig, R., Huglin, C., Laj, P., Lorbeer, G., Maenhaut, W., Mihalopoulos, N., Muller, K., Querol, X., Rodriguez, S., Schneider, J., Spindler, G., Ten Brink, H., Tørseth, K., Wiedensohler, A.: A European aerosol phenomenology-2: chemical characteristics of particulate matter at kerbside, urban, rural and background sites in Europe. Atmos. Environ. 38, 2579-2595 (2004)

Puxbaum, H., Tenze-Kunit, M.: Size distribution and seasonal variation of atmospheric cellulose. Atmos. Environ. 37, 3693-3699 (2003)

Robinson, A.L., Donahue, N.M., Shrivastava, M.K., Weitkamp, E.A., Sage, A.M., Grieshop, A.P., Lane, T.E., Pierce, J.R., Pandis, S.N.: Rethinking organic aerosols: semivolatile emissions and photochemical aging. Science 315(5816), 1259 (2007). doi:10.1126/science.1133061

Schaap, M., Van Der Gon, H.A.C.D., Dentener, F.J., Visschedijk, A.J.H., Van Loon, M., ten Brink, H.M., Putaud, J.P., Guillaume, B., Liousse, C., Builtjes, P.J.H.: Anthropogenic black carbon and fine aerosol distribution over europe. J. Geophys. Res. 109, D18,207 (2004). doi:10.1029/2003JD004330

Schaap, M., Vautard, R., Bergstrom, R., van Loon, M., Bessagnet, B., Brandt, J., Christensen, H., Cuvelier, K., Foltescu, V., Graff, A., Jonson, J.E., Kerschbaumer, A., Krol, M., Langner, J., Roberts, P., Rouill, L., Stern, R., Tarrason, L., Thunis, P., Vignati, E., White, L., Wind, P., Builtjes, P.H.J.: Evaluation of long-term aerosol simulations from seven air quality models and their ensemble in the eurodelta study. Atmos. Environ. (2009, in press)

Schauer, J.J., Kleeman, M.J., Cass, G.R., Simoneit, B.R.T.: Measurement of emissions from air pollution sources. 5. $\mathrm{C}_{1}-\mathrm{C}_{32}$ organic compounds from gasoline-powered motor vehicles. Environ. Sci. Technol. 36, 1169-1180 (2002)

Schell, B., Ackermann, I.J., Hass, H., Binkowski, F.S., Ebel, A.: Modeling the formation of secondary organic aerosol within a comprehensive air quality model system. J. Geophys. Res. 106, 28275$28293(2001)$

Schlesinger, R.B., Kunzli, N., Hidy, G.M., Gotschi, T., Jerrett, M.: The health relevance of ambient particulate matter characteristics: coherence of toxicological and epidemiological inferences. Inhal. Toxicol. 18, 96-125 (2006)

Schmidl, C., Marr, I.L., Caseiro, A., Kotianová, P., Berner, A., Bauer, H., Kasper-Giebl, A., Puxbaum, H.: Chemical characterisation of fine particle emissions from wood stove combustion of common woods growing in mid-European Alpine regions. Atmos. Environ. 42, 126-141 (2008)

Schmidt, H., Derognat, C., Vautard, R., Beekmann, M.: A comparison of simulated and observed ozone mixing ratios for the summer of 1998 in western Europe. Atmos. Environ. 35, 6277-6297 (2001)

Schulz, M., Textor, C., Kinne, S., Balkanski, Y., Bauer, S., Berntsen, T., Berglen, T., Boucher, O., Dentener, F., Guibert, S., Isaksen, I.S.A., Iversen, T., Koch, D., Kirkevå g, A., Liu, X., Montanaro, V., Myhre, G., Penner, J.E., Pitari, G., Reddy, S., Seland, O., Stier, P., Takemura, T.: Radiative forcing by aerosols as derived from the AeroCom present-day and pre-industrial simulations. Atmos. Chem. Phys. 6, 5225-5246 (2006)

Shrivastava, M.K., Lipsky, E.M., Stanier, C.O., Robinson, A.L.: Modeling semivolatile organic aerosol mass emissions from combustion systems. Environ. Sci. Technol. 40, 2671-2677 (2006). doi:10.1021/es0522231

Simpson, D., Guenther, A., Hewitt, C.N., Steinbrecher, R.: Biogenic emissions in Europe. 1. estimates and uncertainties. J. Geophys. Res. 100D, 22875-22890 (1995)

Simpson, D., Yttri, K.E., Klimont, Z., Kupiainen, K., Caseiro, A., Gelencsér, A., Pio, C., Puxbaum, H., Legrand, M.: Modeling carbonaceous aerosol over Europe: analysis of the CARBOSOL and EMEP EC/OC campaigns. J. Geophys. Res. 112, D23S14 (2007). doi:10.1029/2006JD008158

Stern, R., Builtjes, P., Schaap, M., Timmermans, R., Vautard, R., Hodzic, A., Memmesheimer, M., Feldmann, H., Renner, E., Wolke, R., Kerschbaumer, A.: A model intercomparison study focussing on episodes with elevated PM10 concentrations. Atmos. Environ. 42(19), 4567-4588 (2008). ISSN 1352-2310, doi:10.1016/j.atmosenv.2008.01.068

Surratt, J.D., Murphy, S.M., Kroll, J.H., Ng, N.L., Hildebrandt, L., Sorooshian, A., Szmigielski, R., Vermeylen, R., Maenhaut, W., Claeys, M., Flagan, R.C., Seinfeld, J.H.: Chemical composition 
of secondary organic aerosol formed from the photooxidation of isoprene. J. Phys. Chem. 110, 9665-9690 (2006)

Svendby, T.M., Lazaridis, M., Tørseth, K.: Temperature dependent secondary organic aerosol formation from terpenes and aromatics. J. Atmos. Chem. 59, 25-46 (2008). doi: 10.1007/s10874-007-9093-7

Textor, C., Schulz, M., Kinne, S., Guibert, S., Bauer, S., Berntsen, T., Berglen, T., Boucher, O., Chin, M., Dentener, F., Diehl, T., Feichter, H., Fillmore, D., Ghan, S., Ginoux, P., Gong, S., Grini, A., Hendricks, J., Horrowitz, L., Isaksen, I., Iversen, T., Koch, D., Krol, M., Lauer, A., Lamarque, J.F., Liu, X., Montanaro, V., Myhre, G., Penner, J., Pitari, G., Reddy, S., Seland, O., Stier, P., Takemura, T., Tie, X.: Analysis and quantification of the diversities of aerosol life cycles within AeroCom. Atmos. Chem. Phys. 6, 1777-1813 (2006)

Tsikaridis, K., Kanakidou, M.: Secondary organic aerosol importance in the future atmosphere. Atmos. Environ. 41, 4682-4692 (2007)

Tsyro, S., Simpson, D., Tarrasón, L., Klimont, Z., Kupiainen, K., Pio, C., Yttri, K.E.: Modeling of elemental carbon over Europe. J. Geophys. Res. 112, D23S19 (2007). doi:10.1029/2006JD008164

Turpin, B.J., Lim, H.J.: Species contributions to $P M_{2.5}$ mass concentrations: revisiting common assumptions for estimating organic mass. Aerosol Sci. Tech. 35, 602-610 (2001)

Van Dingenen, R., Raes, F., Putaud, J.-P., Baltensperger, U., Charron, A., Facchini, M.-C., Decesari, S., Fuzzi, S., Gehrig, R., Hansson, H.-C., Harrison, R.M., Huglin, C., Jones, A.M., Laj, P., Lorbeer, G., Maenhaut, W., Palmgren, F., Querol, X., Rodriguez, S., Schneider, J., ten Brink, H, Tunved, P., Torseth, K., Wehner, B., Weingartner, E., Wiedensohler, A., Wahlin, P.: A European aerosol phenomenology-1: physical characteristics of particulate matter at kerbside, urban, rural and background sites in Europe. Atmos. Environ. 38(16), 2561-2577 (2004). ISSN 1352-2310, doi:10.1016/j.atmosenv.2004.01.040

van Donkelaar, A., Martin, R.V., Park, R.J., Heald, C.L., Fu, T.M., Liao, H., Guenther, A.: Model evidence for a significant source of secondary organic aerosol from isoprene. Atmos. Environ. 41, 1267-1274 (2007)

Van Loon, M., Vautard, R., Schaap, M., Bergstrom, R., Bessagnet, B., Brandt, J., Builtjes, P., Christensen, J.H., Cuvelier, K., Graf, A., Jonson, J., Krol, M., Langner, J., Roberts, P., Rouil, L., Stern, R., Tarrason, L., Thunis, P., Vignati, E., White, L., Wind, P.: Evaluation of long-term ozone simulations from seven regional air quality models and their ensemble average. Atmos. Environ. 41, 2083-2097 (2007)

Vautard, R., Bessagnet, B., Chin, M., Menut, L.: On the contribution of natural aeolian sources to particulate matter concentrations in Europe: testing hypotheses with a modelling approach. Atmos. Environ. 39, 3291-3303 (2005)

Vautard, R., Builtjes, P.H.J., Thunis, P., Cuvelier, K., Bedogni, M., Bessagnet, B., Honoré, C., Moussiopoulos, N., Pirovano, G., Schaap, M., Stern, R., Tarrason, L., Van Loon, M.: Evaluation and intercomparison of ozone and PM10 simulations by several chemistry-transport models over 4 European cities within the city-delta project. Atmos. Environ. 41(1), 173-188 (2007)

Vautard, R., Martin, D., Beekmann, M., Drobinski, P., Friedrich, R., Jaubertie, A., Kley, D., Lattuati, M., Moral, P., Neininger, B., Theloke, J.: Paris emission inventory diagnostics from ESQUIF airborne measurements and a chemistry transport model. J. Geophys. Res. 108(D17), 8564 (2003). doi:10.1029/2002JD002797

Vestreng, V.: Review and revision. Emission data reported to CLRTAP. Tech. Rep., EMEP MSC-W, http://www.emep.int (2003)

Wexler, A.S., Johnston, M.V.: What have we learned from highly time-resolved measurements during EPA's supersites program and related studies? J. Air Waste Manage. Assoc. 58, 303-319 (2008)

Wiedinmyer, C., Quayle, B., Geron, C., Belote, A., McKenzie, D., Zhang, X.Y., O’Neill, S., Wynne, K.K.: Estimating emissions from fires in North America for air quality modeling. Atmos. Environ. 40(19), 3419-3432 (2006)

Yttri, K.E., Aas, W., Bjerke, A., Cape, J.N., Cavalli, F., Ceburnis, D., Dye, C., Emblico, L., Facchini, M.C., Forster, C., Hanssen, J.E., Hansson, H.C., Jennings, S.G., Maenhaut, W., Putaud, J.P., Tørseth, K.: Elemental and organic carbon in PM10: a one year measurement campaign within the European Monitoring and Evaluation Programme EMEP. Atmos. Chem. Phys. 7, 5711-5725 (2007)

Zhang, Y., Huang, J.-P., Henze, D.K., Seinfeld, J.H.: Role of isoprene in secondary organic aerosol formation on a regional scale. J. Geophys. Res. 112, D20207 (2007). doi:10.1029/2007JD008675 